\title{
THE DIPLOMACY TRAFFIC OF SPANISH HABSBURGS BETWEEN DUBROVNIK AND ISTANBUL (1623-1626)
}

\author{
Cihan YEMIŞÇI \\ Department of History \\ Bilecik Şeyh Edebali University \\ Bilecik, Turska
}

\author{
UDK: $341.71: 94(497.5$ Dubrovnik) \\ DOI: $10.21857 /$ y26kec4zr9 \\ Prethodno priopćenje \\ Prihvaćeno: 17. ožujak 2021.
}

\section{"Dubrovnik, a wheat grain between two millstones"}

The Ottoman-Spanish War that continued through most of the 16th century ended with a semiofficial cease-fire in 1578, although actual hostilities already stopped in 1574. The cease-fire renewal for several times in later years, but neglection of this formality from 1591 onwards. After the Thirty Years War that began in Europe in 1618, to make more effective use of its military forces and financial resources, the Spanish government endeavoured to pacify the Ottoman Empire with a treaty that would neutralise its threatening presence. With this aim, in 1622, the Spanish prime minister Olivares arranged through a Spanish vassal, the viceroy of Naples, to send some representatives to sound out the political mood in Istanbul and pave the way for concluding the treaty Spain desired. Between 1623 and 1626, the English ambassador Thomas Roe, having learned of these representatives' intentions who set out for Istanbul via Dubrovnik, engaged in a diplomatic struggle to protect his country's interests and security. Roe persuaded the French and Venetian ambassadors to ally with him in achieving their common goals. On the other hand, he waged a diplomatic war to obstruct the Spanish government's plans through meetings with Ottoman politicians and lobbying activities.

This research article is about Spain's diplomatic endeavours in Istanbul between the years in question and the struggle to frustrate them by an alliance of ambassadors in the Ottoman capital. The study's primary sources are Thomas Roe's letters and documents in the Dubrovnik State Archive and the Ottoman Archive in Turkey's Department of State Archives.

Keywords: Ottoman Empire, Spanish Habsburgs, Istanbul, Thomas Roe, Dubrovnik, Diplomacy.

\section{INTRODUCTION}

The fascinating story of a series of diplomatic initiatives lies behind an Ottoman firman dated May 1626, addressed to the nobles of Dubrovnik, who were members of the Minor Council (Malo Vijeće). This document's original is in the Dubrovnik State Archive, and there is a copy in the Ottoman Archive. In

** For this comment made by the historian Knolles to express the way Dubrovnik was trapped between the Ottomans and Spain see Joseph W. Zinkeisen, Osmanli Imparatorluğu Taribi, Vol. IV (1299-1453), ed. Erhan Afyoncu, trans. Nilüfer Epçeli, Istanbul, 2011., 174. 
the light of these initiatives, it is possible to point out a characteristic example of how Dubrovnik functioned as a gateway ${ }^{1}$ in and out of the Ottoman Empire for diplomatic missions travelling from Western Europe to Istanbul.

The firman contains an imperious, lordly and threatening command that "the man of the Spanish king"*** coming to start peace negotiations with the Ottomans should be arrested if he is in Dubrovnik. If he has set out for Istanbul, he should be detained on the road and sent back there. A little more investigation into the subject reveals diplomatic endeavours by the Spanish government to sign a treaty with the Ottoman Empire and the intentions behind them.

Madrid's desire to find grounds for peace with Istanbul in the 17 th century first became evident in 1619, but active efforts to put this desire into practice only began in 1623 . The Spanish government took the first step in this direction through the Austrian Habsburg ambassador. They asked to sound out political circles in Istanbul and lay the foundations for eventually signing a peace treaty with the Ottomans. In Istanbul, the English ambassador, Thomas Roe, believed that peace would seriously undermine his own country's interests. This belief led to a diplomatic confrontation with the Habsburg delegation, which arrived on behalf of Spain. To obstruct this Spanish initiative, Roe engaged in effective lobbying of politicians in Istanbul and other foreign ambassadors, and this issue occupied the plan for several years. The correspondence between Roe and the English king's secretary details this political and diplomatic process. Thanks to these documents, the events that took place behind the scene and concealed intentions are revealed. Research by the Austrian historian Joseph W. Zinkeisen has made essential contributions to the subject and shed light on the historical diplomatic process that led to issuing the firman in question.

\section{WAR AND PEACE (!) BETWEEN THE OTTOMANS AND SPAIN}

The war between the Spanish Habsburgs and the Ottoman Empire, the Cross and Crescent, and Eastern and Western poles of the Mediterranean, lasted for much of the 16th century, finally drawing to an end following reciprocal series

1 For this definition see Suraiya Faroqhi, Osmanl Dünyasında Üretmek, Pazarlamak, Yaşamak, trans. Gül Çağalı Güven ve Özgür Türesay, Istanbul, 2008., (3rd edn.), 47.

*** The person referred to as the "the man of the Spanish king" in the document is the representative appointed in the name of Spain by Filiberto, Prince of Savoy, governor of Naples and viceroy (ruler), who was a vassal of Spain. 
skirmishes ${ }^{2}$ during the years 1570-1574. Once established balance of power in the Mediterranean, reduced struggle to a war of harassment on a medium scale, and seas calmed down for both powers' navies. ${ }^{3}$ In 1573 the Ottomans signed a peace with Venice that brought the Cyprus War to an end. At the same time, this meant the dispersal of the last major Crusader alliance and connection on the seas. Both the Ottomans and Spanish desired a truce, and a semi-official ceasefire brought this about in 1578. ${ }^{4}$

Conditions in Europe and the Mediterranean were changing gradually. From 1578 onwards, the Ottoman Empire focused all its attention on the East, where war activities with the Safavids continued for several years. Spain, meanwhile, was entirely preoccupied with the Dutch Revolt. ${ }^{5}$ As a consequence of these developments, both sides were hard-pressed to finance their respective wars and had no resources to fight on a second front. ${ }^{6}$ Moreover, populations around the Mediterranean basin almost doubled over the 16th century, ${ }^{7}$ leading to famines due to insufficient grain reserves in many countries. ${ }^{8}$ At the same time, the military expenditure by Phillip II had exhausted the Spanish treasury and even the gold and silver brought from America was not enough to balance the budget, so forcing Spaniards to declare bankruptcy several times. ${ }^{9}$ During this

2 For details about the conquest of Cyprus during the War of Cyprus in 1570-1573, the Battle of Lepanto in 1571 and the final subdual of Tunisia to Turkish rule in 1574 after changing hands several times, see İsmail Hakkı UzunçARşılı, Büyük Osmanlı Taribi, Vol. III, Ankara, 1995., (7th edn), 9-21, 29-30; Mustafa CezAr, Mufassal Osmanl Taribi, Vol. III, Ankara 2011, 1226-1249; Hüseyin Serdar ТАва коĞLU, Akdeniz'de Savaş, Osmanl-İspanya Mücadelesi, Istanbul, 2019., 219304; Bülent ARI, Akdeniz'de İki Süper Gücün Hakimiyet Mücadelesi, İspanya ve Osmanl, Kibrıs Fethi - Inebahtr - Armada, Ankara, 2019. For detailed information about the Battle of Lepanto, see Alessandro BARBERo, İnebahtı, Ü̧̧ İmparatorluğun Savaşı, Istanbul, 2016.

3 Fernand Braudel, Akdeniz ve Akdeniz Dünyasl, Vol. II, Istanbul, 1989., 131.

4 This cease-fire was not in the form of a treaty ratified by the sultan. The Spanish envoy was only given a document known as temessük in which the grand vezir gave a guarantee of non-aggression in principle for a period of a year. See B. ARI, Íspanya ve Osmanl, p. 58. On diplomatic relations in the years 1577 and 1578 see Stephan Gerlach, Türkiye Günlüğ̈̈ 1577-1578, II, ed. Kemal Beydilli, trans. Türkis Noyan, Istanbul, 2007., 537-538, 541-542, 546, 607, 671-672, 741-743, 861863; H. S. ТАвакоĞLU, Osmanl-İspanya Mücadelesi, 305-310; Emrah NaKI, Akdeniz'de Hakimiyet Mücadelesi, Istanbul, 2020., 171-185. Ayni yillarda Ispanya'nin Dubrovnikte Osmanlilarla esir degisim yapabilmesi için iki sene boyunca elçilik actiginiza dair bknz; Jorjo TADIĆ, Španija $i$ Dubrovnik u XVI stoljeću, Beograd, 1922., 402.

B. ARI, Ispanya ve Osmanl, 70-71.

6 H. S. TAвAKoĞLU, Osmanl-İspanya Mücadelesi, 306-307.

7 F. BRAUdel, Akdeniz Dünyası, I, 270, 272-273, 394, 400.

8 Halil İNalcıк, Osmanl İmparatorluğu'nun Ekonomik ve Sosyal Taribi, Vol. I (1300-1600), trans. Halil Berktay, Istanbul, 2004., 331.

$9 \quad$ F. BRAUdel, Akdeniz Dünyası, I, 336, 342, 361; II, 168-169, 215; B. ARI, İspanya ve Osmanl, 71-72. 
period, precious metals flowing from West to East resulted in the first example of inflation in Europe and Asia, leaving almost no state unaffected. ${ }^{10}$

As a result of these internal and external affairs, forcing Ottomans and Spain to contend, preserving the status appealed to all sides, continuously three years in 1581 and 1584, the cease-fires extended even though these were also ratified only by the grand vezir at the same diplomatic level. ${ }^{11}$ Thus, even if the principle of non-aggression continued in practice till $1619^{12}$, the cease-fire arrangements stopped very early in reality. Still, in the meanwhile, we have coordinated the Spain-Napoli attempt in 1600 by throwing emissary to Ottomans. ${ }^{13}$

The Ottoman-Habsburg wars affected the Republic of Dubrovnik in many respects, both positively and negatively. This city-state made too innovative use of its strategic position as a neutral region between the two poles of the Mediterranean. Serving in various roles enhanced its geopolitical importance, such as providing intelligence services ${ }^{14}$ and diplomatic and

10 Carlo M. Cipolla gives an illuminating account of how silver pouring from America into Spain and continuing from there to the Ottoman Empire, and on as far as China, caused price rises in every country it passed through, upsetting market balances. See Carlo M. Cipolla, Fatibler, Korsanlar, Tüccarlar, trans. Tülin Altınova, Istanbul, 2003.

11 B. ARI, Ispanya ve Osmanl, 66-69.

12 Between two dates when renewal of the cease-fire had been neglected, an earthquake that occurred in 1609 caused the walls around the fortress of Castelnuovo to collapse, and a Spanish fleet of 32 ships took advantage of this situation to approach within one or two miles. The governor was away fighting in the Transylvanian Campaign, and the town's defences were weak in the wake of the disaster. The defterdar (minister of finance) of Bosnia came to the rescue and fired the cannons, forcing the fleet to withdraw. See Kâtib ÇELEBI, Fezleke [Osmanlı Tarihi (1000-1065/1591-1656)], Vol. I, ed. Zeynep Aycibin, Istanbul, 2016, 418.

13 J. TADIĆ, Španija i Dubrovnik u XVI veku, 406.

14 Nicolaas H. Biegman, Ragusan Spying for the Ottoman Empire: Some 16th Century Documents From the State Archive at Dubrovnik, Belleten, XXVII/106, Ankara, 1963., 237-255; Zdravko ŠUnDRICA, Obavještajna služba Dubrovačke Republike u 18. stoljeću (Epizoda austrijsko-turskog rata 1737-1739., Anali Zavoda za povijesne znanosti HAZU u Dubrovniku, 37, Dubrovnik, 1999., 162-165; Vesna Miović, Dubrovačka Diplomacija u Istanbulu, Zagreb-Dubrovnik, 2003., 127-140; Vesna Mrović, Dubrovačka Republika u Spisima Osmanskih Sultana, Dubrovnik, 2005., 47-50; Robin Harris, Dubrovnik, A History, London, 2003., 97, 104; Emrah Safa Gürkan, Sultanın Casusları, 16. Yüzyılda İstihbarat, Sabotaj ve Rüşvet Ağları, Istanbul, 2017., 254; Metin Ziya KösE, Osmanl Devleti ve Dubrovnik İlişkileri, 1500-1600, Doğu Akdeniz'de Casuslar ve Tacirler, Istanbul, 2009., 20; Mladen Glavina, 17. Yüzyıl Başında Osmanlı Imparatorluğu ile Dubrovnik Cumburiyeti İlişkileri (master's degree thesis), Ankara, 2009., 29-33; Özlem KumRular, Kurtlar Sofrasında Bir Cambaz: Şehir-Devlet Ragusa, Türk Tarihinde Balkanlar, Balkans in the Turkish History, Vol. I, ed. Zeynep İskefiyeli, M. Bilal Çelik and Serkan Yazıc1, Sakarya, 2013., 469.

15 For example, during the reigns of Bayezid II (1481-1512) and Süleyman I (1520-1566), the Ottomans hired shipbuilding engineers from Dubrovnik to work in the Albanian ports.; see Jorjo TADIć, Organizacija dubrovačkog pomorstva u XVI veku, Istorijski časopis, 1-2, SANU, Beograd, 1948., 60, and based on this source also see M. Glavina, 17. Yüzyıl Başında Osmanlı-Dubrovnik İlişkileri, 31. 
logistic support ${ }^{15}$ to both sides' hosting war prisoner swappings. ${ }^{16}$ So although peace was a highly desirable end, the static situation mentioned above did not significantly influence Dubrovnik's geopolitical situation. First of all, as a neutral port open to international trade, Dubrovnik earned hugely increased revenues in times of war. ${ }^{17}$

Consequently, the arrival of peace reduced the port's profits, especially considering when the Port of Spalato's harmful effects. Moreover, with the end of hostilities, Dubrovnik's strategic importance dwindled. As the need for intelligence from Dubrovnik became less pressing ${ }^{18}$ and large scale exchanges of prisoners of war kept no more in the city, ${ }^{19}$ the city's role as a gateway in and out of the Ottoman Balkans for European diplomats came more to the fore.

The people of Dubrovnik transported marine equipment in their galleons to the Ottomans during the War of Cyprus and sent master shipbuilders to Ottoman dockyards. In addition, on Istanbul's request, they sent tools, journeymen and master builders to build and repair fortresses as part of preparations for war.; see the Directorate of State Archives Ottoman Archive (BOA), Mühimme Defteri (A. DVNS. MHM. d.), no: 6, doc. nos: 1145 and 1146 (14 Şevval 972 / 15 May 1565); no: 7, doc. no: 1218 (10 Şevval 975 / 8 April 1568). On the logistic support given to the Ottomans by the Ragusans also see V. Miović, Dubrovačka Republika u Spisima Osmanskih Sultana, 48.

16 On large scale exchanges war prisoner swappings that took place in Dubrovnik in 1538, 1575 and 1592-1593 see Cihan Yemişçı and Muhamed ValjevaC, Türk Esirlerin Kurtarılması ve Mübadelesinde Bir Merkez Olarak Dubrovnik ve 1575 ile 1592 Yıllarındaki Esir Mübadeleleri, Uluslararası Türk Savaş Esirleri Sempozyumu Bildiri Kitabı (14-15 Mart 2017, Istanbul), eds Okan Yeşilot, Yüksel Çelik, Leyla Coşan and Ali Satan, Istanbul, 2018., 103-109; Nicolaas H. BıEGmaN, The Turco-Ragusan Relationship according to the Firmans of Murad III (1575-1595) extant in the State Archives of Dubrovnik, The Hague, Paris, 1967., 145-147; V. Miović, Dubrovačka Republika u Spisima Osmanskih Sultana, 51; Ahmet ÖNAL, XVI. Yüzyılda Avrupa'daki Osmanlı Esirlerin Kurtarılması Meselesine Dair Bazı Gözlemler, Türkiye - Almanya Araştırmaları Dergisi, IV/1-2, Istanbul, 2015., 49-52.

17 When the customs revenues of the Port of Dubrovnik are examined, it is immediately evident that enormous increases took place during periods when the Ottomans and Venetians were at war. For example, port revenues calculated at 17,000 ducats for 1535-1537 rose sharply to 52,000 ducats over 1538-1541. During two periods of peace between the Ottomans and Venetians in 1552-1555 and 1560-1569, however, port revenues were just 19,700 and 26,000 gold ducats respectively, but when hostilities resumed between the two states in 1570-1572, the customs revenues of the port soared to 106,000 gold ducats. Later on, during the subsequent period of peace, port revenues for 1576-1580 and 1591-1600 again dropped to normal levels, at 28,000 and 2,.000 gold ducats respectively, see Bariša KRE KIĆ, Dubrovnik in the 14th and 15th centuries: a city between East and West, Norman 1972, and based on this source also see H. İNALCı K, Osmanl İmparatorluğu'nun Ekonomik ve Sosyal Taribi, I, 318.

18 Towards the end of the 16th century Istanbul took over the role as centre of intelligence. See Emrah Safa Gürkan, Bir Diploma si Merkezi Olarak Yeniçağ Istanbul'u, Antik Çağ’dan XXI. Yüzyıla Büyük Istanbul Tarihi, Vol. II (SiyasetveYönetim), ed. Coşkun Yılmaz, Istanbul, 2015., 372-399; the same author, Sultanın Casusları, 161-177; and M. GLAvinA, 17. Yüzyıl Başında Osmanl-Dubrovnik İlişkileri, 37.

19 The last major exchange of prisoners in Dubrovnik took place in 1592-1593. See YemişçI, VALJEVAC, Esir Mübadeleleri, 109-120. 
Another unfavourable result of peace for Dubrovnik was that the Mediterranean's struggle left power quest to pirates. The Habsburgs supported the Maltese, Tuscans and Uskoks against the Turks, while the Ottomans exceeded control through pirates based in North Africa and Dalmatia. ${ }^{20}$ As the Ottoman capital's authority over the provinces regularly declined in this period, pirates began to attack the ships and lands of countries with which the Ottomans were at peace. Both the Venetians and Ragusans were adversely affected by this. ${ }^{21}$ Still, the southern coast of Spain and the Italian coastal cities under Spanish rule were worst affected, given the pirates' existence. For nearly a century, Spain had spent large sums on constructing fortifications and strengthening existing ones to defend against the Ottoman corsairs who repeatedly attacked Italy's shores. ${ }^{22}$ Also, Spain had to send military garrisons totalling twenty thousand men to Naples, Sicily, Sardinia and Corsica, and allocate ten thousand soldiers and 60 ships manned by eighteen thousand slaves to battle against pirates sea. ${ }^{23}$

Like many other maritime states, the Venetian Republic was pleased to see Spain and its vassals falling into difficulties, despite its problems with Ottoman pirates. On the other hand, Dubrovnik viewed the Ottomans' navies, Spain and Spanish vassal states such as Osuna as balancing factors that could thwart Venetian ambitions to achieve hegemony in the Adriatic and Venice's hostile intentions towards Dubrovnik itself. The Habsburgs were also disturbed by how

20 Maurice Aymard, XVI. Yüzyılın Sonunda Akdeniz'de Korsanlık ve Venedik, trans. Mehmet Genç, Istanbul Üniversitesi İktisat Fakültesi Mecmuasi, 26, Istanbul, 1963., 220; Alberto Tenenti, Piracy and the Decline of Venice, 1580-1615, trans. J. B. Pullan, Oxford and London, 1967., 25; İdris Bostan, Adriyatik'te Osmanlılar ve Uskoklar, Beylikten Imparatorluğa Osmanlı Denizciliği, Istanbul, 2007. (2nd edn), 112-113; İdris Bostan, Adriyatik'te Korsanlık, Osmanlllar, Uskoklar, Venedikliler 15751620, Istanbul, 2009., 36; İdris Bostan, Adriyatik Limanlarının Ticari Bakımdan Gelişmesine Korsanlığın Etkisi, XIV. CIEPO Sempozyum Bildirileri (18-22 Eylül 2000, Çeşme), TTK., Ankara, 2004.; Machiel KIeL, "Avlonya", Türkiye Diyanet Vakfi İslam Ansiklopedisi (TDVIA), Vol. IV, Istanbul, 1991., 119; Machiel KIEL, "Draç", TDVIA, IX, Istanbul, 1994., 522-524; Skender RIzAJ, "Dalmaçya", TDVIA, VIII, Istanbul, 1993., 432-433.

21 V. Miović, Dubrovačka Republika u Spisima Osmanskih Sultana, 123-128; M. Glavina, 17. Yüzyıl Başında Osmanl--Dubrovnik İlişkileri, 108-111; Cihan Yemişçı, XVII. Yüzyılda OsmanlıDubrownik Siyasî İlişkileri (unpublished doctoral dissertation), Istanbul, 2017., 185-219.

22 This form of war reduced to a medium intensity that the Ottomans carried on through corsairs weakened Spain both psychologically and economically. Despite building fortifications against the Turkish pirates in the Spanish and Italian islands and coastal cities, and the erection of towers and reinforcement of defensive walls in Sicily, defence lines remained inadequate. On this and the serious problem with payments, see F. BRAUDEL, Akdeniz Dünyası, II, 136, 139-140.

23 Ahmet BÜYÜKaKsoY, İngiltere’nin Istanbul Elçisi Thomas Roe'nun Diplomatik Yazışmaları (1621-1628) (unpublished master's degree thesis), Istanbul, 2012., 333. Roe's letter written from Istanbul to Secretary Calvert in November - December 1623, 332-334; J. W. ZinkeISEN, Osmanl Imparatorluğu Taribi, IV, 163. 
the Venetian Republic saw the Adriatic Sea as its private gulf. After 1616, they took action to undermine this hegemony using fleets belonging to the Duke of Osuna. He was the Spanish viceroy in Naples. ${ }^{24}$

At the political summit held in Madrid at the beginning of the 17th century, starting diplomatic channels with Istanbul was essential to restrain Ottoman pirates, who proved to be impossible to deal with by other means. In this way, the idea emerged that a possible peace could resolve the issue or that negotiations could set a time frame for halting the pirates' threat. The Spanish government drew up this plan for talks to remedy the eroding and draining effects of maintaining two fronts against the Ottomans and the other against its enemies in ongoing wars in Europe. If this plan worked, Spain would transfer its troops deployed in the Central Mediterranean and Italian coastal cities and the money allocated to fortifications to other fronts. Consequently, the Spanish government saw this plan as a method of freeing up its troops for action against Flanders the other Protestant princes and Venice, and so put it into effect. ${ }^{25}$

\section{IMPROVEMENTS BETWEEN 1619 AND 1622 IN ISTANBUL}

Spanish diplomatic activities in the Ottoman capital began in 1619 after the Thirty Years War broke out in Europe. In this war, the Spanish and Austrian Habsburgs were the main actors against the Protestant principalities. ${ }^{26}$ Since the Austrian ruler was a member of the other branch of the Habsburgs, the Madrid government hoped to have Spain included in the Treaty of Zitwa signed between the Ottomans and Austria to renew the treaty. With this intention, the government was confident that it would be possible to open diplomatic doors and advisement for Spain with the Ottoman government through the mediation of the Austrian ambassador Baron Mollart. Meanwhile, some Jews and Jesuits in Istanbul prepared the ground for Spanish representatives by sounding out the capital's mood and endeavouring to influence it in favour of Spanish diplomatic initiatives. ${ }^{27}$ However, Protestant ambassadors had only recently held talks

24 Vinko Foretić, Povijest Dubrovnika do 1808 godine, Vol. II, Dubrovnik, 1980., 86; R. HARRIS, Dubrovnik, 119. The cease-fire agreement for twelve years between Spain and Flandersfinished in 1621.

25 In the last twenty years of the 16th century, the cease-fire between Spain and the Ottomans enabled the Spanish to withdraw its forces in Italy to reinforce its army fighting in France. See F. BRAUDEL, Akdeniz Dünyası, II, 387.

26 On the reasons for the Thirty Years War in Europe and the course of the war see Stephen J. LEE, Avrupa Taribinden Kesitler 1494-1789, Ankara, 2019., (7th edn), 109-130.

27 J. W. ZIN KeIsen, Osmanlı Imparatorluğu Tarihi, IV, 161-162. 
with politicians in Istanbul, informing them of current tensions between the Netherlands and Austria.

Moreover, the Ottomans were known to favour the Netherlands and the Protestant principalities. Therefore, they had taken an aloof stance towards Austria, which caused Spanish hopes of peace to fall through in 1619. Moreover, the Austrian massacre of Czech Protestants in Prague on 8 November 1620 exacerbated the situation further. ${ }^{28}$

As time went on and this issue lost its importance, Austrian diplomats were again able to establish a certain degree of trust in the Ottomans' relations. So in 1622, after Count-Duke Olivares, who advocated the Spanish policy of peace with the Ottoman Empire, became prime minister, they decided to launch the plan. However, Olivares preferred to conduct these peace negotiations through Naples's governor rather than directly sending an ambassador from Spain. ${ }^{29}$

On the other hand, the political atmosphere in Istanbul was extraordinarily mixed and rough. Osman II (1618-1622) was overthrown and killed due to a revolt by the janissaries. After him, Mustafa I (1617-1618, 1622-1623), who was mentally ill, succeeded him and was crowned to the Ottoman throne. After 1622, the five-year period of rebellions and power struggles between factions began in the capital. Dozens of high-ranking servers and officers lost their lives because of this crisis, so the government and central administration were unstable and changed many times. For example, during the reign of Mustafa I, five grand vezirs in a small amount of time came to power. ${ }^{30}$ In all this confusion and disorder, Bekir Sübaşı, who was the commander in chief of Baghdad troops of the Ottoman Empire, got out of control, rebelled and declared that he would

28 J. W. Zinkeisen, Osmanl İmparatorluğu Taribi, IV, 163.

29 S. FAROQhi, Osmanlı Dünyasında Üretmek, 46-47. It is no coincidence that Spain and Austrian Habsburgs chose this indirect diplomatic approach to contact the Ottoman Empire during fast and rapid developments of progressive capitalism and Age of Enlightments ideas. Such an approach, portraying them as superior that the enemy begs for mercy and cooperation, making contact throughout someone as a part of grace and mercy, is recorded in the political theories of Machiavelli and the political practice of Count Stefan de Montesquieu de Orlean. This approach and way was generally recognized and widespread practice during the 16th and 17th Century. For even further information, Noel Malcolm, Useful enemies, Islam and the Ottoman Empire in the Western Political Thought, London I, 2019., 221.

30 From May 1622, when Osman II was murdered, to September 1623, when Murad IV came to the throne, we can observe unsteable diversity in grand vizier succesions: Davud Paşa, Mere Hüseyin Paşa (2 times), Kemankeş Ali Paşa and Çerkes Mehmed Paşa. See I. H. UzunçArşıLI, Osmanlı Imparatorluğu Taribi, III, s. 141-149. In addition, for the period of political crisis in question see same pages. 
surrender the city to Safavid shah of Iran. ${ }^{31}$ Due to this chaotic and anarchic environment that interfered with capital affairs, postponing Spanish diplomacy's Istanbul plan activities seems the best choice.

The Austrian ambassador who arrived in Istanbul to congratulate Mustafa I on his second accession to the throne in 1623 received instructions to settle out and investigate the atmosphere in the capital towards peace with Spain. Also, to prepare the ground for launching direct arrangements and negotiations between the two states if he considered this appropriate, and with this aim to promise the release of around two thousand Ottoman galley slaves from Spanish ships. However, Spain was then on the brink of war with states that included Ottoman allies; it contained a suspicious proposal. Moreover, the Austrian Emperor's ambassador Kurz von Senftenau fell foul of the Ottoman policy of viewing Austria and Spain as separate states, and his initiative got rejected. ${ }^{32}$

Spain must have seen this first step towards making peace sufficient for continuing its strategic plans because it began to withdraw its troops from Italy, where they served against the Ottoman threat. Von Senftenau also had witnessed in Istanbul that the Ottoman could not pose a threat in that period. Hence, therefore, to redirect funds allocated for defending Sicily and Naples against the Turks to meet its army's needs in Europe. ${ }^{33}$

\section{SPANISH DIPLOMATIC INITIATIVES IN 1624 AND 1625 AND THOMAS ROE'S COUNTER-ATTACKS}

In 1624 Isaac Cormoran, a Jew in the guise of a Christian, was appointed to be a secret representative charged with launching peace negotiations on Spain's behalf in Istanbul. In anticipation of his arrival, the Benedictine monk

31 Bekir Sübaşı besieged the castle where the governor of Baghdad, Yusuf Pasha, with whom he had a dispute, caused the governor's death and declared that he would give the city to the Safavid shah. Bekir only stopped on Hafiz Ahmed Pasha, appointed as the governor of Baghdad from Istanbul, marching on Baghdad with the army due to the negotiations between them. The governorship of the city given to Bekir with the rank of pasha. During these developments, there were also tense letter exchange between Hafız Ahmed Pasha and Karçıkay, the commander of the Safavid shah, who came to take over Baghdad. See I. H. UzunçARşıLI, Osmanlı İmparatorluğu Tarihi, III, 153157.

32 See A.Büyü Ka ksoy, Roe’nun Yazışmaları, p. 333 (in the letter from Roe to Secretary Calvert written from Istanbul in November - December 1623, 332-334); J. W. ZINkEISEN, Osmanlı Imparatorluğu Tarihi, IV, 163-164.

33 A. BüyüKaksoy, Roe’nun Yazışmaları, 367-368 (Sir Dudley Carleton's letter to Thomas Roe, 22 February 1623, 366-368). 
Antonio Berill won the sympathy of the powerful chief black eunuch and the sultan's sister. ${ }^{34}$ They had persuaded Grand Vezir Kemankeş Ali Paşa to hold discussions with the ambassador. ${ }^{35}$ But when Cormoran arrived in Edirne, he turned back to hear about Ali Paşa execution on 3 April. So now it was necessary to persuade his successor, the new grand vezir, Çerkes Mehmed Paşa. ${ }^{36}$

When the English ambassador Thomas Roe heard about Cormoran's mission, he was concerned that this peace would have adverse consequences for England. He immediately gave the matter top priority and took steps to deal with it. He wrote to London about the situation, and the threat was taken seriously by the government. Shortly afterwards, since Spain's peace plan also had repercussions for Venice, Roe warned the Venetian bailo in Istanbul. In this way, Roe established a diplomatic alliance with the Venetian bailo against the Spanish schemes and secured the Venetian government's cooperation through the bailo. With his new ally, the chessboard supposedly laid out for diplomatic

34 "Starting the second half of the XVI. century, the influence and power of women belonging to the dynasty started to increase in the Ottoman palace. Since Selim II (1566-1574), the growing power of the palace agas (different head departments) with dynasty women increased due to the abandonment of the crown princes from being sent to the sanjaks with forced captivity in the capital precisely in the palace. The crisis started with the early death of Sultan Ahmed I (1603-1617) was so deep and massive. It affected all cells of society and civilization. This crisis was especially noticed and made a significant remark on the Ottoman central authority and government. Kösem Sultan, without any doubt, left the most effective mark over this crisis. Osman II was her stepson and later on crowned Murad IV, and Sultan Ibrahim were all her children. In addition to the high-rank officers supported by Kösem Sultan, she also got help from the palace agas (different head departments). Ahmet Refik named this period "The Reign of Women". For this reason, Berill and his successors, who understood the pulse of politics in Istanbul well, would direct and lead the Habsburg ambassadors and representatives to the dynasty women and palace agas and high-ranking officials in Istanbul for lobbying affairs. See Ahmet Refik Altinay, Kösem Sultan, Kadınlar Saltanatı, İstanbul 2011; Reşad Ekrem KoçU, Kösem Sultan, İstanbul, 2015.; Mücteba İlGüREL, Kösem Sultan, Türkiye Diyanet Vakfi Íslam Ansiklopedisi, XXVI, Ankara, 2002., 273-275. The sultan's authority temporarily restored from 1627, when IV. Murad was 16 when he took the reins of power until he died in 1640".

35 It appears that Ali Paşa took a possible peace with Spain seriously and sent letters to the Naples viceroy asking him to send an authorised Spanish ambassador. Roe argued that this would be attributed to Ottoman weakness by Spain and undermine morale and confidence among the empire's allies. See Thomas Roe, The Negotiations of Sir Thomas Roe, in His Embassy to the Ottoman Porte, from the Year 1621 to 1628, London, 1740., 324; A. BÜYÜKAKsoY, Roe'nun Yazışmalar, 571 (discourse the note addressed to the kaymakam (deputy to the grand vezir) about the Treaty of Buda by Sir Thomas Roe, dated 20 January 1624, 570-571).

36 A. BÜYÜKaksoy, Roe’nun Yazışmaları, 443-444 (Roe'dan Haberler, Istanbul, 24 Temmuz 1624, pp. 441-444) ve 447-448 (Relations from Constantinople, 7 August 1624, pp. 446-448); J. W. ZinkeIsen, Osmanlı Imparatorluğu Taribi, IV, 164. 
moves in Istanbul to thwart Spanish plans. On orders received from the English government, Roe and the Venetian bailo in Istanbul were to take action. ${ }^{37}$

In 1625, Battista Montalbano of Bologna was charged with the same task as Cormoran and sent as an emissary to Istanbul. ${ }^{38}$ When he arrived in the capital, instructions were to enter the protection of the Austrian ambassador Lustrier, make contacts with the Greek Jesuit Cannachi Rossi and the Benedictine monk Berill. They would inform him of their views and ideas plus give their assistance. In addition, they supplied him with generous funds and diplomatic gifts to win over Ottoman politicians and influential palace officials. The Spanish government instructed Montalbano to make the following promises in the negotiations: ${ }^{39}$

1. First of all, a long-term peace treaty will be set up between the two states.

2. Upon ratification, Spain would release 400 Ottoman slaves.

3. Spain would refrain from attacks on Ottoman coasts and harming Ottoman subjects or their property.

4. Spanish Merchants and traders would sell spices, linen, delicate fabrics, and similar goods shipped from India via the Red Sea to the Ottoman Empire at much cheaper rates than the English and Dutch, resulting in large Ottoman profits from extensive Ottoman profits customs duties.

5. The Spanish king would interact with the Polish king to pull up the Cossacks ${ }^{40}$ and prevent their plundering and pillage in the Black Sea region.

37 A. BÜYÜKaksoy, Roe’nun Yazışmaları, 487-488 (letter from Sir George Calvert to Roe dated 1 October 1624). Roe was informed that England had cooperated with Venice to have Cormoran followed and that the Venetian bailo was contacted for the purpose of arresting him with the letters and orders he was carrying. See the same dissertation, 541 (letter from Sir George Calvert to Roe, Istanbul, 24 October 1624, 540-541).

38 For Roe's letter telling his superior that he has discovered Montalbano's identity and mission and describing this in detail, see A. BÜYÜKAKsoY, Roe'nun Yazı̧̧maları, 700 (letter from Roe to Sir Edward Conway, 28 July 1625, 700-705).

39 Thomas Roe, The Negotiations of Sir Thomas Roe, in his Embassy to the Ottoman Porte, from the Year 1621 to 1628, London, 1740., 455; A. BÜYÜKAKsoy, Roe'nun Yazışmaları, 700 (from Roe to Sir Edward Conway, 28 July 1625, 700-705); 712 (Relations from Roe to Sir Edward Conway, Istanbul, 12/22 August 1625, 711-714) and Relations of 11 August 1625, 714; J. W. Zinkeisen, Osmanl Imparatorluğu Taribi, IV, 165-166. Attention: Roe's words quoted from the book "The Negotiations..." published in London in 1740. The footnotes where the book pop out, chapters in this book have been checked by comparing with Büyükaksoy's thesis.

40 Towards the end of the 16th century, the Ukraine Cossacks crossed the Black Sea to plunder Ottoman settlements in the Eastern Balkans and then extended their piracy to Istanbul. See Yücel

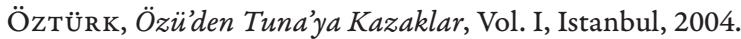


If the Ottomans approved of these conditions and promises, ${ }^{41}$ Montalbano accompaniment would be an official Spanish ambassador. If not, the representative's funds would further evoke and excite the Cossacks against the Ottomans hegemony, diverting Ottoman attention to the Black Sea coast and hampering their policy of assisting the Transylvanian prince Bethlen Gabor against Austria. ${ }^{42}$

The Spanish emissary Montalbano arrived in Istanbul in June 1625, travelling via Dubrovnik. ${ }^{43}$ Despite giving the role of an ambassador with extensive powers, ${ }^{44}$ exercising plan to lie low, pretending to be a member of Austrian ambassador Lustrier's entourage, until the ambassador had discovered the attitudes held by Ottoman high-ranking officials. These officials, however, had grave doubts about taking part in negotiations with Spain. Regarding this initiative as a delaying tactic by Spain, they did not take it seriously, and Lustrier's interview with the grand vezir did not go well. The grand vezir curtly rejected his proposal that the sultan gives Montalbano an audience. Giving reasons as "For these 40 years, wherein the vizier had served in a Public Office: He never saw any sincere disposition in the king of Spain to seek peace, nor any messenger directly from him which made this new and sudden kindness suspicious; disavowing... that neither the Emperor [the sultan], nor he, knew anything of the affair. So that ever any such thing was in question or consultation here; therefore he might return from whence he came, and do his business with them that employed him". ${ }^{45}$

41 Roe informed his superior of the disastrous consequences posed by this situation, “... the Spanish treaty; which, if it proceeds, will destroy all our Southern and Eastern trades”. See T. RoE, The Negotiations, 439; A. BÜYÜKAKsoy, Roe'nun Yazı̧̧maları, 726 (Roe’s letter to Lord Conway, Heybeliada, 24 September 1625, 725-726).

42 A. BÜYÜKaksoy, Roe'nun Yazışmalar, p. 700 (letter from Roe to Sir Edward Conway, Istanbul, 28 July 1625, 700-705) and 747 (letter from Roe to Sir Edward Conway, Istanbul, 4/14 November 1625, 746-751); J. W. Zinkeisen, Osmanl Imparatorluğu Taribi, IV, 166.

43 Roe informed the English government that Montalbano had set foot in Dubrovnik 28 days before the date of his letter. Roe also explained that he was well supplied with money to pay for diplomatic gifts for distribution in the capital and admitted that he knew nothing about the proposals he would make so far. He added that faced with this new peace proposal (since the issue was still in the early stages) he could not predict what stance the Ottomans would take. Roe's state of anxiety due to his misgivings are reflected in the letter. See A. BÜYÜKAKsoY, Roe'nun Yazı̧̧maları, 688 (Roe's letter to Sir Edward Conway, Istanbul, 10 June 1625, 688-690); J. W. ZIn KeISEN, Osmanlı Imparatorluğu Taribi, IV, 166.

44 T. Roe, The Nagotiations, 422-424; A. BÜYÜKAKsoy, Roe'nun Yazışmaları, 700 (letter from Roe to Sir Edward Conway, 28 July 1625, 700-705). In the Ottoman diplomacy protocol, the sultan would only accept official ambassadors before. Diplomatic representatives, on the other hand, could only meet with the grand vezir.

45 T. Roe, The Nagotiations, 419; A. BÜYÜKaksoy, Roe'nun Yazışmaları, 695 (Letter from Roe to Sir Edward Conway, Heybeliada, 13/23 July 1625, 693-696); J. W. ZIN KeISEN, Osmanlı İmparatorluğu Tarihi, IV, 168. 
The outbreak of war expectations between the Austrian and Spanish Habsburgs and Venice were imminent. The Ottoman government was aware that if they agreed to start peace talks, they would put their ally Venice ${ }^{46}$ and their vassal Bethlen Gabor in a problematic position concerning their shared enemy, the Habsburgs. So the Ottomans could not possibly risk giving any advanced opportunity to Spain, regarded as their "ancient enemy", ${ }^{47}$ mainly since this was Spain's intention. Therefore, the officials took an unsympathetic view towards this move, which did not tally with official Ottoman policy..$^{48}$ That year, the sultan offered troops' military assistance under the command of the governor of Bosnia to support La Serenissima (the Republic of Venice), which was then beleaguered by the Habsburgs issued a firman permitting the Venetians to gather a force of mercenaries from Albania. ${ }^{49}$ Habsburg forces had recently advanced close to

46 "If the Spanish gain this peace, their galleys will be at liberty to attack in the Gulf of Venice. Their garrisons at Calabria, Sicily and Sardinia and on the coast will be free for service in Italy. From there, it could estimate that they will be able to deploy 20,000 men in the other direction, which will have grave consequences"; For more see A. BÜYÜKAKsoY, Roe'nun Yazışmalar, 689 (Letter from Roe to Sir Edward Conway, Istanbul, 10 June 1625, 688-690).

47 The grand vezir told Roe that Spain was regarded as the "ancient enemy" of the Ottomans and guaranteed that no official peace talks would occur. But for Roe's continuing anxieties on this subject, see BÜYÜKAKsoy, Roe'nun Yazı̧̧maları, 688-689 (Letter from Roe to Sir Edward Conway, Istanbul, 10 June $1625,688-690)$. In 1626, confident that the Ottoman inclination was now definitely opposed to peace negotiations with Spain, Roe wrote: "it was very unreasonable, at this time, to leave old friends for old enemies; and that the league made between the emperor, Spain, the pope, and Poland, was alike dangerous to this state, as to ours. We did believe, in this enterprise, nothing aimed at, but to work some disunion among the [Protestant] princes colleagued, by fears, which no other practice could yet bring to pass: and lastly, that it would ruin our trade, upon which the friendship depended." See T. RoE, The Nagotiations, 509; A. BÜYüKaKsoY, Roe'nun Yazı̧̧aları, 829 (Letter from Roe to Sir Edward Conway, Istanbul, 6-16 May 1626, 828-830).

48 From the beginning of the 1620 s, early on in the Thirty Years War, due to the threat posed by counterattacks on Venetian ships and lands by fleets under Spanish control, during the reign of Osman II (1618-1622), orders were sent to administrative and military officials on the Adriatic coast to ally with the Venetians. Firmans sent to the sub-provincial governors of Scutari, Delvina and Valon, and the kadis and fortress commanders of these towns, and army officers in the region. Copies of which also sent to the sub-provincial governors, kadis and army officers in Klissa, Herzegovina, Krka and Durres, commanded them (if necessary) to assist the Venetian navy against the Spanish and to fight as allies with the Venetians. See BOA, Maliyeden Müdevver Defter (MAD. d.), no: 6004, 14/1 and 16/1 (Evâhir-i Cemâziyelevvel 1030 / 13-22 April 1621); S. FAROQHI, Osmanl Dünyasında Üretmek, 46; Cihan Yemişçı, 1618-28 Arası Osmanl-Venedik İliş̧kileri (master's degree thesis), Selçuk Üniversitesi Sosyal Bilimler Enstitüsü, Konya, 2009., 190.

49 The Ottoman sultan drew up another firman responding to the war being waged close to the gate of Venice by the governor of Milano. The latter was subject to Spain, with the particular aim of protecting and defending Valtellina. For the firman commanding the governor of Bosnia to take his forces to the aid of the Venetians if the latter requested military support. It was also sent to some sub-provincial governers such as those of the Morea, Delvina, Scutari, and Ioannina, permitting the Venetians to raise mercenaries in the lands under their control see BOA, MAD. d., no: 6004, p. 
Valtellina, which linked Venice to Central Europe, and cut off La Serenissima's land route to its ally France. To repel the threat of invasion across Venetian borders and reopen the path of communication with France, the Venetians were massing troops in the region. Also, an infringement of Venetian supremacy in the Adriatic, which the Republic viewed as its internal sea, had taken place. A Spanish fleet found in 1624, consisting of 17 ships - nine Sicilian, four Genoese and four Maltese - had entered the "Gulf of Venice", so illicitly entering Venetian waters and posing a threat to its navy..$^{50}$

Meanwhile, through their contacts in Istanbul, the Spanish diplomatic service continued its investigations behind the scenes to learn how to send gifts to Ottoman officials and turn the government's sympathies in their favour. Indeed, agents working for the Spanish made some progress in these efforts. For example, he persuaded three of the sultan's sisters, his privy chamberlain, his doorkeeper, Admiral of the Fleet Topal Receb Paşa and former Janissary Commander Bayram Paşa to exert their influence on the sultan concerning starting peace negotiations. Moreover, it appears that the sultan listened to them and remained under their power for a while. This development led to the expectation that the Spanish ambassador would give at least a "safe conduct passage" for his proposed journey. ${ }^{51}$

113/2 (Evâhir-i Rebiülâhir 1034 / 31 January - 8 February 1625); S. FAROQHI, Osmanlı Dünyasında Üretmek, 46; Yemişçi, 1618-28 Arası Osmanl1-Venedik İlişkileri, 189. For records kept by the Venetian bailo of firmans, commands, hüccets and letters see Serap Mumcu, Venedik Baylosu'nun Defterleri, The Venetian Baylo's Registers (1589-1684), Hilâl. 4, Edizioni Ca' Foscari, Venedik 2014, p. 197 (Letters nos: 419, 420 and 421), p. 199 (no: 426), pp. 199-200 (no: 427), pp. 200-201 (no:430), p. 201 (no: 431), p. 202 (no: 435) and p. 203 (no: 439). For Roe's observations in his letters regarding this development also see A. BÜYÜKa KsoY, Roe’nun Yazışmalar, 579 (letter from Roe to Sir George Calvert, Istanbul, 7/17 February 1625, 577-579). In addition to these, a firman warning Ottoman pirates on the coasts of Dalmatia not to engage in cooperation against Venice, particularly with the Spanish, is of note here. Keeping Ottoman pirates in check reflected the policy of allowing Venice to wage its struggle against Spanish forces. With as little difficulty as possible (the firman addressed to the sub-provincial governors, kadis, fortress commanders and army officers of Klissa, Herzegovina, Krka and Racesne [Rahović ?]). See S. Mumcu, Venedik Baylosu'nun Defterleri, The Venetian Baylo's Registers (1589-1684), Hilâl., 158 (Letter no: 313). What is meant by the Spanish naval forces was the naval fleet of the duke of Osuna. He was the Spanish viceroy in Naples, and which was deliberately harassing Venetian warships. See V. FORETİ́, Povijest Dubrovnika do 1808 godine, II, 86; R. HAR RIs, Dubrovnik, 119.

50 V. Foretić, Povijest Dubrovnika do 1808 godine, II, 91.

51 Roe wrote his discoveries regarding Montalbano and those assisting him, "[I found that] the noise of it afar off had procured many friends, and infected some of the credit near the grand signor." For this letter, see T. RoE, The Negotiations, 452; A. BÜYÜKaksoy, Roe'nun Yazışmalar, 746 (Letter from Roe to Sir Edward Conway, Istanbul, 4/14 November 1625, 746-751). In addition, Roe's relates that "... a practising priest, or Benedictine friar ... conveys much matter into the Seraglio, 
The grand vezir had already received Montalbano's proposals with suspicion and found them exaggerated, so Roe concentrated on comments designed to rouse and incite these suspicions even more during conversations with him. He said that Montalbano had not received official credentials or a reference letter endorsed by the Spanish king. If he had been sent officially by Naples' ruler (viceroy), the Spanish king would easily deny any prelude that made. He added that in Spain, it created an attempt to give the impression that it was the sultan who was suing for peace rather than it is an initiative of the Spanish government. Therefore, the proposals would bring dishonour to the sultan. He also said that rumours spread about a Spanish ambassador who would arrive after Montalbano were untrue. He added that it was inconceivable that the Pope in the Vatican would initial such peace and the promises made in the proposals. $\mathrm{He}$ also asserted that the Spanish guarantees were based on false information and refuted the requests one by one, explaining why they did not make sense. His argument that these initiatives intent to distract the Ottomans and thereby gain time and advantages for the Habsburgs while they were engaged in war elsewhere was Roe's most potent and practical move. Finally, Roe requested and insisted on informing the sultan and preserved observations..$^{52}$

Roe went on to hold talks with the Grand Vezir's deputy ${ }^{53}$ and other politicians and palace officials, ${ }^{54}$ at which he endeavoured to persuade them in the same way.

at the women's back doors, all concurrent, and arrived within one month: and though yet this Spanish instrument play least in sight, conspiracies hatched in the dark, and such is any friendship between Spain and Turkey" and that the grand vezir is aware of the conspiracies going on behind the scenes: "the Vizier hath either discovered, that his moyles [efforts] are behind", see T. RoE, The Negotiations, 419; A. BÜYÜKaksoy, Roe'nun Yazı̧̧maları, 695 (Letter from Roe to Sir Edward Conway, Heybeliada, 13/23 July 1625, 693-696); J. W. Zinkeisen, Osmanlı Imparatorluğu Tarihi, IV, 169.

52 T. RoE, The Nagotiations, 455-456; A. BÜYÜKAKsoY, Roe'nun Yazı̧̧malar, 751-754 (discourse given by Roe to the grand vezir about the Spanish treaty proposal, Istanbul, 2 October 1625); J. W. Zin KeISEN, Osmanlı Imparatorluğu Tarihi, IV, 168-171.

53 For Roe's meeting with the kaymakam, who explained that he was persistent about preventing this peace and that if he could not succeed, he would resign. How in another interview, the kaymakam told Roe that he had given orders to the paşa of Buda that there was no need for a new peace because there was still 16 months until the Treaty of Zitwa with Austria expired. The sultan would act under the old treaty, see T. RoE, The Nagotiations, 453; A. BÜYÜKa Ksoy, Roe'nun Yazışmaları, 746-747, 748 (Letter from Roe to Sir Edward Conway, Istanbul, 4/14 November 1625, 746-751); J. W. Zinkeisen, Osmanl Imparatorluğu Taribi, IV, 169, 171-172.

54 T. RoE, The Nagotiations, 452; A. BÜYÜKaksoy, Roe'nun Yazı̧̧malar, 747 (Letter from Roe to Sir Edward Conway, Istanbul, 4/14 November 1625, 746-751); J. W. Zinkeisen, Osmanl Imparatorluğu Taribi, IV, 171-172. “... there was danger in the heat of other spirits, openly and earnestly prosecuted the obtaining of safe conduct. Therefore I went a little further, to open the eyes of the mufty, the bustangee bassa, and some other great ministers". 
According to Roe, the Spanish hoped to achieve another aim by keeping peace talks and eliminating the risks posed by Italy's withdrawing Spanish troops. It means they planned to combine their forces with their Austrian counterpart to attack the Protestant German principalities, take control of the roads to Italy, and gain an advantage over Bethlen Gabor. ${ }^{55}$ Convinced by this argument, the vezir's deputy refused Lustrier's request and did not have an official talk to Montalbano. ${ }^{56}$

Roe managed to raise the red alarm in diplomatic circles at the Ottoman capital by exerting all his diplomatic skills and powers of persuasion in his lobbying activities. ${ }^{57} \mathrm{He}$ first warned the Venetian bailo and then the French and Dutch ambassadors against their common enemy's intentions and succeeded in getting them to cooperate. Thus, thanks to Roe's efforts, the Istanbul ambassadors are already alert about Montalbano's activities.

While this was going on, they discovered after the grand vezir had refused to meet Montalbano, the monk Berill had placed down about provoking the Cossacks against the Ottomans. As a result, the governor of Silistra arrested the monk, who carried letters to Montalbano and the viceroy of Naples. When news of this reached Montalbano, he left Istanbul in a hurry. ${ }^{58}$ Still, the Austrian ambassador continued his convincing and supportive talks with people who sympathised with his support for an Ottoman-Spanish peace, ${ }^{59}$ paving the way for a new attempt in this direction. ${ }^{60}$

55 A. BÜYÜKAKsoY, Roe'nun Yazışmaları, 754 (a discourse about the proposed Spanish treaty given to the grand vezir by Roe, Istanbul, 2 October 1625, 751-754); J. W. ZinkeISEN, Osmanl Imparatorluğu Taribi, IV, 171.

56 T. RoE, The Negotiations, 452; A. BÜYÜKAKsoy, Roe'nun Yazı̧̧malarl, 746 (Letter from Roe to Sir Edward Conway, Istanbul, 4/14 November 1625, 746-751); J. W.ZIn KeISEN, Osmanl İmparatorluğu Tarihi, IV, 172. “... But the great gate [Sublime Porte] was shut; the kaymakam would never give him an audience, nor admit of any treaty, perhaps expecting more reality [official approach]: so that he [Montalbano] forced to practice in the dark".

57 Roe requested that Ottoman officials give him the text of the Treaty of Zitwar, which was concluded in 1606 and later renewed. Examining the treaty articles he found that they couldn't be accepted, meaning that it was impossible to include the Spanish king in the peace. About this examination carried out by Roe and the Dutch ambassador see A. BÜYÜKAKsoY, Roe'nun Yazı̧̧malar, 1118 (Roe's interview with the vezir at the request of the administrator of Magdeburg Istanbul (undated), 1117-1120); also see 1127 (Roe's interview with the vezir, Istanbul, 10 November 1627, 1125-1128).

58 A. BÜYÜKaksoy, Roénun Yazışmaları, 747 (Letter from Roe to Sir Edward Conway, Istanbul, $4 / 14$ November 1625, 746-751). In the days ahead, Roe was to learn the reasons behind this hurried departure and add these developments to his letter. See p. 751; J. W. Zinkeisen, Osmanl Imparatorluğu Taribi, IV, 172. Also, see Roe's letter about the same events to the Bishop of Canterbury, 794 (793-796).

59 A. BÜYÜKaKsoY, Roe’nun Yazışmalar, p. 748 (Letter from Roe to Sir Edward Conway, Istanbul, 4/14 November 1625, 746-751).

60 “The emperor's envoy has opened a fresh way to a Spanish treaty. The messenger previously sent here [Montalbano] has returned to Naples. Concerning that matter a decision about sending the 


\section{THE REPRESENTATIVE OF SPANISH-CONTROLLED NAPLES TURNED BACK FROM DUBROVNIK IN 1626}

Up till this time, the Spain court had chosen not to send an official ambassador to Istanbul. The well-known Spanish diplomatic pride did not allow the government to lose face with the Spanish public, Europe and the Vatican by taking the first step towards peace with the Ottomans and demeaning itself by being the supplicant. ${ }^{61}$ Consequently, the government preferred the indirect method of sending preliminary representatives to pave the way for an official ambassador. Furthermore, they resolved to keep engaging in talks and peace negotiations with the Ottomans as a secret. Simultaneously, the government took steps at home to create the impression that the sultan was proposing peace negotiations - a leaflet bearing the forged signature of the sultan, specially printed for this purpose. Besides, books declaring that the sultan had pleaded for peace were published and distributed throughout the Christian world ${ }^{62}$.

Furthermore, one of Spain's former representatives, the Jew Cormoran, was sent from Naples to Madrid in a sultan's representative's guise. ${ }^{63}$ However, Roe warned the grand vezir of these activities, so exposing a ruse. As a result, both the Spanish palace and government were humiliated, and the incident caused the Ottomans to take a much more defiant stance. ${ }^{64}$

ambassador or the more dangerous course of exerting influence by sending money [to the Austrian ambassador] is awaited within fourteen days", see A. BÜYÜKAKsoy, Roe’nun Yazışmaları, 798 (Letter from Roe to Sir Edward Conway, Istanbul, 25 February 1625, 797-799).

${ }_{61}$ In 1577 during endeavours to initiate peace negotiations between the Ottomans and Spain, the latter avoided sending a real envoy. However, faced with the determined stance of the Ottomans, Philippe II was obliged to send some representatives. These Spanish representatives were ashamed of being recognised as they went around Istanbul and desired that their negotiations with the Ottomans be top secret. They covered their faces as they came and went to these negotiations. For them, this was equal to being "made small in the eyes of the Turks". See J. W. Zinkeisen, Osmanl Imparatorluğu Taribi, III, 356-357.

62 A. BÜYÜKAKSOY, Roe'nun Yazı̧̧malar, 754 (discourse given by Roe to the grand vezir about the Spanish treaty proposal, Istanbul, 2 October 1625, 751-754) and 829 (letter from Roe to Sir Edward Conway, Istanbul, 6-16 May 1626, 828-830). As an example of the leaflets mentioned by Roe, see Archivo General de Simancas (AGS), Copia de la carte (1625), shelf marked BNE, VC/224/64. My thanks to Hüseyin Serdar Tabakoğlu for sharing this example with me.

63 A. BÜYÜKaksoY, Roe’nun Yazışmaları, 594 (letter from Roe to Sir Edward Conway, Istanbul, February 1625, 592-595; J. W. ZIN KeISEN, Osmanl Imparatorluğu Taribi, IV, 173.

64 "... I had lately received a letter ... the wholly false and ridiculous. So I translated this and gave copies to the great ministers, commenting thereupon, as was requisite: at which they took such great disdain that they resolved to give no admittance to any Spaniard, nor to listen to any treaty. I first dealt with the Mufti and the heads of the law. Who encouraged me to go to the Kaymakam, and to acquaint him with the arrival of this new gentleman, and to ask a command to meet him on the way", see T. RoE, The Negotiations, 509; A. BÜYÜKA Ksoy, Roe'nun Yazışmalar, 829 (Letter from Roe to Sir Edward Conway, Istanbul, 6-16 May 1626, 828-830). 
In April 1626, the viceroy of Naples sent another representative supplied with "an official letter of reference" informing the Republic of Ragusa and the Ottoman government that a Spanish diplomatic delegation would soon be leaving out, designed to obtain the right of safe passage for the representative from both these states. Naturally, news of the representative's arrival received intense disfavour in Istanbul. The representative arrived in a galliot in Dubrovnik, expecting a state welcoming ceremony, realising none of his expectations, so he hid away in a nearby monastery. Later on, the Naples representative showed the authorities in Dubrovnik a letter addressed to them that he claimed had been sent by the grand vezir. On the strength of this letter, Dubrovnik appointed two Ottoman officials to take him to Istanbul. Upon receiving this news, the Venetian bailo immediately took steps to prevent the representative from being received by the Ottoman government in consultation with the English and French ambassadors. ${ }^{65}$ As a result of lobbying by these ambassadors in Istanbul, ${ }^{66}$ the Ottoman government instructed the authorities in Dubrovnik to immediately arrest the representative if he was still in the city or set out for Istanbul to stop him on the road and send him back Naples. ${ }^{67}$

The Naples representative had already set out from Dubrovnik and travelled for nine days when he fell from his horse and broke three bones. He was taken back for treatment to Dubrovnik, where he was secretly given refuge in the Monastery of Saint Dominicos. ${ }^{68}$ Then, however, Ottoman officials demanded

65 Roe explained that this letter, which he describes as "extraordinary", to the Venetian bailo had arrived from the Venetian governor of Kotor 10 gün earlier.; For more see T. RoE, The Negotiations, 508; A. BÜYÜKAKsoY, Roe'nun Yazı̧̧maları, 828, 829 (Letter from Roe to Sir Edward Conway's mektubu, Istanbul, 6-16 May1s 1626, 828-830).

66 Roe described these stages as a witness to the writing and sending of the firman: "This day [6 May] upon the occasion of the expedition of the commands for Ragusa, we met ... This command we have, with reasons and gifts obtained; and another to Ragusa, to admonish that republic, not to intermeddle hereafter, nor to assist in the passage of any minister of the king of Spain ... Today we dispatch them by four horsemen, with instructions to watch all ways, and safely to conduct this gentleman out of these dominions." See T. RoE, The Negotiations, 509, 510; A. BÜYÜKAKsoY, Roe'nun Yazışmaları, 829-830 (Letter from Roe to Sir Edward Conway, Istanbul, 6-16 May 1626, 828-830) and 831 (Letter from Roe to Sir Edward Conway, Istanbul, 8 May 1626, 830-831). Also see J. W. Zin KeIsen, Osmanl İmparatorluğu Taribi, IV, 173.

67 For the firman see Državni Arhiv u Dubrovniku (DAD), Diplomata et Acta(DA.), Acta Turcarum $(7 / 2.1)$, sv. 16, br. $787(\mathrm{~A} 8,111)$ and for the copy recorded in the Ottoman records: BOA, MAD. d., no: 6004, p. 125/3 (Evâsit-1 Şa ban 1035 / 8-17 May 1626). A reproduction of the original document, its transcription and English translation are in the Appendices. For a Croatian translation of the firman see V. Miović, Dubrovačka Republika u Spisima Osmanskih Sultana, 55-56.

68 Roe wrote this on 23 May 1626 and gave the news that the four horsemen carrying the firman had set out 18 days earlier. See A. BÜYüKaKsoy, Roe'nun Yazışmaları, p. 838 (Letter from Roe to Sir Edward Conway, Istanbul, 5 June 1626, 838-841).; For even further and deatiled information, on 
that the Dubrovnik authorities hand him over. Still, they refused, afraid that this would harm Dubrovnik's good relations with the Spanish and the city's neutral status and concerned that this would violate the Republic's rights as an independent state. So the Naples representative was put on board ship under the observant eye of Ottoman officials and sent back to Naples. Afterwards, the Senate wrote a letter to the grand vezir explaining their actions and offering their apologies. ${ }^{69}$

After sending a new Ottoman firman, a new deputy grand vezir, "sadaret kaymakamı", was appointed. Since this new officer was a paşa who belonged to the faction supporting peace with Spain, Roe anticipated a renewed diplomatic initiative from Spain. However, he was not too anxious since he was confident that the new high admiral, who had no sympathy towards Spain, would counterbalance against the deputy grand vezir. ${ }^{70}$

In 1627, while both Ottoman officials and united ambassadors in Istanbul expected the Habsburgs to make another bid for peace with Spain, an experienced state official of French birth, Rodolpho Kyllmye, was appointed Austrian ambassador. He arrived in Dubrovnik on a Neapolitan ship. He presented his passport from the kaiser and letters from Naples's ruler (viceroy) to the Senate and documents of safe conduct, given by Murtaza Paşa, the Ottoman governor of Buda. They were probably influenced by their recent experiences the previous

emissary path and leaving the Dubrovnik, positive and negative events, accidents as well written statement of witnesses we can follow from Mirjana Polıć Boвıć, Među križom i polumjesecom, Zagreb, 2000., 180-203.

69 "Our messengers sent to Ragusa re returned, having found the Neopolitan gentleman in the city; and delivering their letters to the duke and magistrates, required that he would be hand over to them: but they refused to infringe so far their liberty, but promised that they would execute the grand signor's will; and to that purpose wrote a cold letter to the kaymakam, of complement, fearful of offending either Spain or this state ... The Ragusan ambassadors are daily expected [in Istanbul ], with their tribute, whom we know to be half Spaniards. Yet, we will procure such caution to be handed over to them that at least, they shall stand neutral in this business." See T. RoE, The Nagotiations, 538; A. BÜYÜKaKsoy, Roe'nun Yazı̧̧malar, 879 (Letter from Roe to Sir Edward Conway, Istanbul, 31 July 1626, 875-880); J. W. Zinkeisen, Osmanlı Imparatorluğu Taribi, IV, 173174.

70 A. BÜYÜKaksoy, Roe'nun Yazışmaları, p. 856 (Letter from Roe to Sir Edward Conway, Istanbul, 5 July 1626, 855-856). Roe also stated, "The treaty with Spain, I hope, hath received a deadly wound; for though our messengers, sent with the command to Ragusa, are not returned, yet we hear, that they have laid all passage. In every city, divulged that no Spanish minister might admit; and we doubt not they have found the gentleman employed and conducted him safely out of these dominions." See T. RoE, The Nagotiations, 530; A. BÜYÜKAKsoY, Roe’nun Yazı̧̧malar, 864 (Letter from Roe to Sir Edward Conway, Istanbul, 16 July 1626, 858-865). Roe also wrote a letter to the queen of Bohemia, giving her this news, see A. BÜYÜKA KsoY, Roe'nun Yazışmaları, 867 (Istanbul, $16-26$ July $1626,865-868)$. 
year. The Ragusans did not want the ambassador to remain long in the city, and two days after landing in the port, they sent him to Istanbul. Due to misgivings in the Ottoman capital, they took the ambassador into custody to prevent him from meeting the former Austrian ambassador, who was still in the city. Subsequently, he was received by a vezir, not a courtesy, but an interrogation. The chosen route makes him suspicious: If he was the ambassador of the kaiser, why had he not gone via Buda, which was the entrance to Ottoman territories from Vienna, and met with Murtaza Paşa? Why had he instead taken the long and circuitous route via Naples and Dubrovnik? All these questions and suspicions put him in surveillance and custody.

After Kyllmye had assured the vezir that he had no mission relating to Spain and no reference from that country, he examined his documents, passport, and authority letter. Once suspicions that he might be a Spanish agent had been relieved, they sent him to Buda, where issues relating to the kaiser, whose ambassador he claimed to be, were discussed. ${ }^{71}$

\section{CONCLUSION}

If the Ottoman Empire had signed a peace treaty with Spain, it would have a disastrous impact on England's commercial interests in the Levant and throughout the Mediterranean. These developments would have been equivalent to closing the Straits of Gibraltar to the English. However, indirectly it might have positively affected that country's trade relations with Venice and France. Undoubtedly, that would have been a blow to English interests in the Mediterranean and Dutch parts for the same reasons. ${ }^{72}$ Even though Dutch commercial activities were focused principally on the ocean routes, in 1612, Ahmed I (1603-1617) issued a document declaring that the Ottoman Empire recognised the Netherlands as an independent state and gave the Dutch permission to trade the Levant.

Meanwhile, there were many other adequate reasons - relating to security, not concerning trade-for France and Venice feeling at least as much anxiety as England about a possible Ottoman-Spanish peace. The enmity, hostility between these two states and Spain were at their peak, and the war was likely to break out at any moment. Since the Habsburgs still had troops in Italy, they were a

71 A. BÜYÜKaksoy, Roe’nun Yazışmaları, 996-998, 1001 (Letter from Roe to Sir Edward Conway, Istanbul, 17-27 February 1627, 995-1002).

72 For Roe's comments see A. BÜYÜKAKsOY, Roe’nun Yazışmaları, 829 (Letter from Roe to Sir Edward Conway, Istanbul, 6-16 May 1626, 828-830); J. W. Zinkeisen, Osmanlı İmparatorluğu Taribi, IV, 167. 
threat to Venice, so the Venetian alliance with the Ottomans and its military power were strategically important. Following the conquest of Valtellina by the Spanish governor of Milano, war broke out first with Venice and in 1628 with France. At this point, the neutralisation of the Ottomans through a peace treaty with Spain would, above all, seriously undermine the French-Venetian alliance against Spain.

From the Republic of Dubrovnik's point of view, this peace would probably have no adverse impact; indeed, it might claim that it would be highly beneficial in terms of both its security and strategic situation. Both sides offered advantages for the political and commercial interests of the city-state and its security. On the one hand, the Republic was a "faithful and obedient tributary state" of the Ottoman Empire. On the other hand, it maintained good relations with most Italian city-states, vassals of Spain. These long-standing political and commercial relations went back for centuries. A peace that would resolve the divisive polarity in the Mediterranean, which had marked the previous century and whose effects had carried on into the $17^{\text {th }}$ century, would eliminate the Dubrovnik Republic's risk of being caught between the two sides in this quarrel and suffering adverse consequences. Espionage carried out by Dubrovnik on behalf of the Ottomans had sometimes put the Republic in a difficult position in its relations with Spain. Everyone was aware that some Dubrovnik captains had aided the Spanish fleet in times of war. During the Spanish-Ottoman wars of the second half of the $16^{\text {th }}$ century, the English, French and Venetian ambassadors had frequently complained to the sultan about the Republic's support for the Spanish forces, which dismayed the Ragusan ambassadors. ${ }^{73}$ Meanwhile, both the Spanish and

73 Over the last thirty years of the 16th century, the Venetian, English and French ambassadors in Istanbul allied in a campaign to blacken Dubrovnik's reputation. Since the events on which they based their claims were partly true, this put the Ragusan envoys in a challenging situation when they were called on to explain themselves to the sultan. The main arguments put forward by the Ragusan ambassadors were that the help and support given to enemies of the Ottomans were the work of Ragusan sea captains acting on their initiative, and that the Republic could do nothing to stop them apart from prohibitions and legal sanctions. Accusations brought against them plus events on which these settled are as follows: On the claim that during the wars of 1570-1573, the Spaniards had made their base in Dubrovnik harbour during their attacks the Ottoman navy. They had obtained supplies from here, see Muzaffer ARI KAN and Paulino ToLEDo, XIV.-XVI. Yüzyzllarda Türk-İspanyol İlişkileri ve Denizcilik Tarihimizle İlgili İspanyol Belgeleri, Ankara, 1995., p. 307. On the presence of Ragusan ships in the allied navy at the Battle of Lepanto in 1571, when the Ottoman navy had suffered a resounding defeat. For even further information check out, J. TADIĆ, Španija i Dubrovnik u XVI veku, 400; see V. Foretić, Povijest Dubrovnika do 1808 godine, II, 60. In 1588, Ragusan captains with a total of 176 ships joined the Spanish naval force at different levels during the war waged by Spain against England and the Netherlands. The affair of the Twelve Apostles called fleet belonging to the Ragusan Ohmučević family was the most notorious and shameful. 
Ottoman navies seized Ragusan ships for their fleets during this war period. They caused diplomatic crises by the Ottoman discovery that Ragusan ships had supported the Spanish navy. ${ }^{74}$

On the other hand, signing a peace treaty between the Ottoman Empire and Spain, how secure would the city of St. Blaise and the city state's territory have been against Venetian aggression? Moreover, would Spanish naval attacks on Venetian ships have resulted in any advantages for Dubrovnik's Mediterranean trade? Although they speculated that these questions' answers would be affirmative, no definite answers were possible since peace had never been concretely established and signed.

From this time onwards, Spain's power began to decline, and the country became less and less of a threat to the Ottomans. ${ }^{75}$ One sense, the year 1626 was when Spain made its last bid as a power to be reckoned with in the Mediterranean, after which Iberia, the Western pole of the region, faded from the scene. ${ }^{76}$ As the losing side in the Thirty Years War, Spain was no longer an enemy the Ottomans

Three of these ships captured by the Ottomans in 1594. Dubrovnik declared that "Ohmučević had betrayed Dubrovnik because of a grudge against the country and entered the service of the Spanish king". This fleet was also used in the 1590s to provoke an Irish uprising against the English. These ships met various bad ends, but the same family and some other Ragusans continued to serve Spain. In 1592 the Venetian, English and French ambassadors presented a joint petition against the Ragusans to the Ottoman government. In this petition, they declared that the Ragusans had built 12 ships for the Spanish king in their territory and that corn and other grain for which they had obtained permission from the Ottomans to export to Dubrovnik were shipped to Spain. See R. Harris, Dubrovnik, 104-105. The aid of this kind that the Republic was unable to prevent despite genuine efforts was by no means inconsiderable. So much so that between the years 1584-1654, almost three hundred Dubrovnik ships served the Spanish navy in various capacities. See N. H. Biegman, The Turco-Ragusan Relationship, 127-128; İdris Bostan, Adriyatik'te Korsanlik, 61-62; M. Glavina, 17. Yüzyıl Başında Osmanl-Dubrovnik İlişkileri, 34. Venetians tried legitimating attacks on Dubrovnik and its territory in 1617 in the eyes of the Ottomans, claiming that the Ragusans had assisted the Spanish. See I. Bostan, Adriyatik'te Korsanlik, 62, 73.

74 V. Foretić, Povijest Dubrovnika do 1808 godine, II, 64-71.

75 J. W. Zinkeisen, Osmanl Imparatorluğu Taribi, IV, 174.

76 Braudel gives the main reason for this as the extravagant Spanish spending of their wealth in American gold and silver. Due to Spain's dependence on foreign countries for its food supplies and huge war expenses, the metals were flowing from America squandering markets. Unlike England, Spain did not use this wealth for production and industrialisation. As a result, the metals that entered the Iberian peninsula were not kept in the country, but after a short time, poured eastwards. See Freud BRAudel, Akdeniz Dünyasl, I, 323; II, 168-169, 215. Also, for interesting and detailed information about the journey and route taken by Spanish silver from America, see C. M. Cipolla, Fatibler, Korsanlar, Tüccarlar. The fact, that the incoming silver failed to stay in Spain led to the bankruptcy of the Spanish government in 1557, 1575, 1607 and 1627. See F. BRAUDEL, Akdeniz Dünyast, I, 342, 361; II, 180. The quantity of metal arriving from America slowed down in the first decade of the 17th century and particularly from the second decade onwards, and by the middle of the century had largely stopped altogether. See F. BRAUDEL, Akdeniz Dünyası, I, 362-363. 
needed to consider after $1648 .{ }^{77}$ From this time onwards, the Ottomans were more preoccupied with the problems caused by Florentine and Maltese pirates in the Mediterranean..$^{78}$ Once Spain had lost its importance in the struggle for supremacy in the Mediterranean and Europe, representing no obstacle at the Ottoman capital or a diplomatic representative sent from Istanbul to Madrid. So the Ottoman government had no misgivings about sending a representative to Spain in 1649, appointing Ahmed Ağa as Ottoman representative to Madrid. ${ }^{79}$ Again Dubrovnik was his departure point out of the Ottoman territory and the entry point on his return journey. ${ }^{80}$

This series of diplomatic initiatives were the last incidents to put the Republic of Dubrovnik in difficulties regarding its position between the Ottoman Empire and Spain. Thus, this was the end of Dubrovnik's situation as "a grain of wheat between two millstones" in the historian Knolles. ${ }^{81}$

77 S. J. LeE, Avrupa Taribi, 124-130.

78 J. W. Zinkeisen, Osmanli Imparatorluğu Taribi, IV, 175-178.

79 For information about Madrid days of Ahmed Ağa, his interviews with Spanish statesmen and diplomatic experiences, see Jorge Fernández-Santos and Hüseyin Serdar TabakoĞLu, The Unexpected Ottoman Guest: Ahmed Agha in Madrid (1649-50), Ambassadors in Golden-Age Madrid, The Court of Philip IV through Foreign Eyes, ed. Jorge Fernández-Santos and José Luis Colomer, Madrid, 2020., 379-423.

80 DAD, DA., 7/2.1, sv. 22, br. 1027 (K 471) (Evâhir-i Cemâziye'l-âhir 1059 / 1-10 Temmuz 1649) ve sv. 23, br. 1069 (K 513) (Evâil-i Rebi'ü'l-âhir 1060 / 3-12 Nisan 1650).

81 J. W. Zinkeisen, Osmanlı Imparatorluğu Taribi, IV, 174. 


\section{APPENDICES}

Appendix 1: 'The firman dated May 1626, commanding and sending that the Spanish representative back from Dubrovnik'.

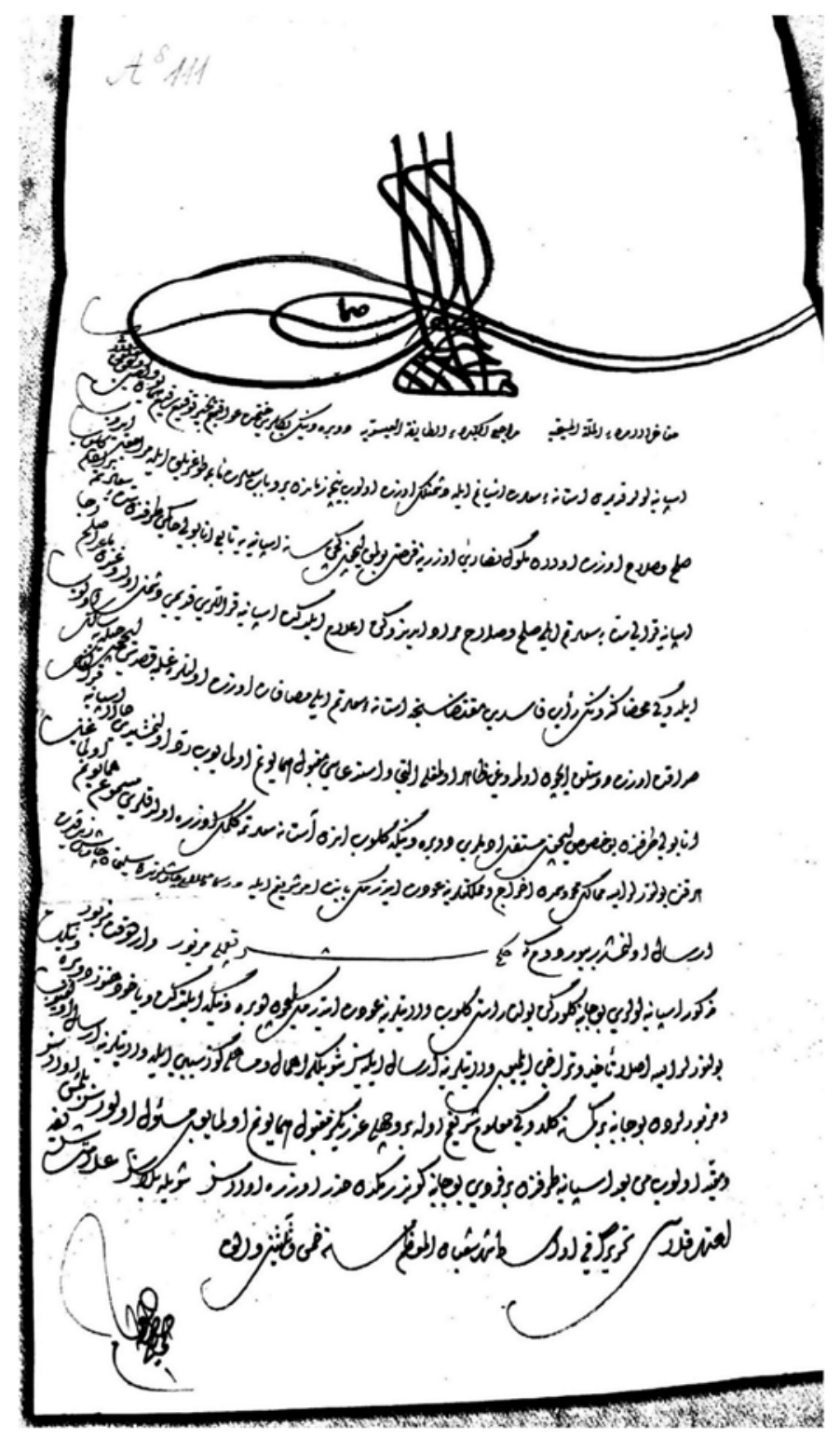

Source: DAD, DA., 7/2.1,sv. 16, br. 787 (A 8, 111) (Evâsıt-1 Şa'ban 1035 / 8-17 May 1626). 
APPENDix 2: Transcription of the firman

\section{TUĞRA}

Mefâhiru'l-ümerâ'i'l-milleti'l-Mesîhiyye merâci'u'l-küberâ'i't-tâifeti'l-İseviyye Dubrovnik beyleri hutimet 'avâkıbubum bi'l-hayr tevkî'-i refî́-i hümâyûn vâsıl olıcakma' lûm ola ki,

Ispanyalular kadîmden Âsitâne-i Sa'âdet-i Âşiyânım ile düşmanlık üzere olub nice zamândan berü Bâb-ı Sa'âdet-me 'âbıma doğruluk ile mürâca'ât idüb sulh ü salâh üzere olan mülûk-ı Nasârî üzerine firsat bulmak içün geçen sene İspanya'ya tâbi Anabolı (Naples) hâkimi tarafindan Südde-i Sa'âdetim'e bir adem gelüb İspanya kralı Südde-i Sa' âdetim ile sulh ü salâh murâd idindüğgin $\hat{\imath}^{\prime} l a ̂ m$ eyledikde İspanya kralları kadîmî düşman olduğından máadâ sulh ricâ eyledüği mahzâ kendünün raib kasdı muktezâsınca Âsitâne-i Sa'âdetim ile musâfât üzere olanlara galebe kasdı içün hîleye sâlik olub sadâkat üzere dostluk içün olmaduğı zâhir olmağla ilticâ ve istida'âsı makbûl-ı hümâyûnum olmayub redd olunmuşdı hâlâ İspanya kralının Anabolı tarafindan bu husûs içün müstakil ademleri Dubrovnik'e gelüb andan Asitâne-i Sa'âdetim'e gelmek üzere oldukları mesmû'- hümâyûnum olmă̆ın hareketde bulunurlar ise Memâlik-i Mahrûsem'den ibrâc ve memleketlerine 'avdet itdirmek bâbında emr-i şerîfim ile Dergâh-ı Mu' allâm çavuşlarından Süleyman Çavuş zîde kadrehu irsâl olunmuşdur.

Buyurdum ki,

Hükm-i şerîfimle mezbûr vardukda mezkûr İspanyalular bu cânibe gelürken yolda rast gelüb vilâyetlerine 'avdet itdirmek içün Dubrovnik'e iletdikde veyâhud henüz Dubrovnik'de bulunurlarsa aslâ te 'hîr ve terâhi eylemeyüb vilâyetlerine irsâl eyleyesiz şöyle ki ihmâl ve müsâhelenüz sebebi ile vilâyetlerine irsâl olunmayub ve mezbûrlardan bu cânibe bir kimesne geldüği ma' lûm-ı şerîfim ola bir vechle 'özriniz makbûl-ı hümâŷ̂num olmayub mes 'ûl olursız bilmiş olasız ve mukayyed olub min ba'ad Ispanya tarafindan bir ferdi bu cânibe göndermekden hazer üzere olasız şöyle bilesiz 'alâmet-i şerîfe i' timâd kalasız.

Tahrîren fî Evâsıt-ı şehr-i Şa'bânü'l-mu'azzam sene hams ve selâsîn ve elf'. 
Appendix 3: English translation of the firman

TUGHRA (The sultan's monogram)

May the praiseworthy rulers of the Christian people and the lords of Dubrovnik, which is one of the great authorities among the followers of Jesus, know from reading this firman bearing our sublime monogram that the Spaniards have anciently been enemies of our seat in the Felicitous Capital. For a long time, to create an opportunity to fulfil its ulterior motives regarding the Christian countries applied to our Sublime Gate insincerity, peace and fidelity. Naples, subject to Spain, has sent a man to our Felicitous Threshold and declared that the Spanish king desires peace and commitment with our Felicitous Threshold. Being our ancient enemies, our realisation that Spain's request for peace is a sham aimed only at deluding us to win victory over the genuine friends of our Felicitous Capital and has no real intention of friendship based on loyalty. Therefore, this application was not given our illustrious acceptance but rejected.

Again regarding the same matter, a man was sent from Naples, subject to the Spanish king, and arrived in Dubrovnik. It came to our illustrious notice just as he was about to set out for my Felicitous Capital. My honourable command that if he had set out, he would be deported from our country and sent back home delivered by the hand of Süleyman Çavuş, one of the highly esteemed palace messengers.

When this person arrives, I command to bring my honourable command to meet the Spaniards in question on his way there. In that case, he should take them to Dubrovnik to deport them to their country. Or find them still in Dubrovnik that you should send them back to their country immediately and without delay. However, if we discover they have not been sent home to their country through your neglect and procrastination, so they passed into our territory, know that we will accept no excuse. You shall be held responsible under all circumstances. And take this matter seriously, make sure that you send no one from Spain to use in the future. Know that this is so and place trust in our honourable sign [the tuğra].

Dated and written in the middle of Şa'bân of the year of the Hegira 1035 (8-17 May 1626 AD). 
APPENDIX 4: Leaflet printed in Spain, with the fake peace proposal supposedly made by the sultan

\section{R E G N I,}

\section{ET STA T I D E L R E F I L I P P O, E T} DEL GRAN TVRCO CON LB LORO ENTRATE, ET SPESE.

ET ALTRE COSE NOTABILL.

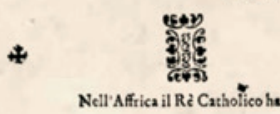

IL Regnod'Orano, con ls fuppriorita del Regno di Tenis. L'tole Canarie , \& il Peri divifo in molti Regni.

L Spagna , che comprende i Regai, di Caftiglia, Toledo, Lione, Grasuta, Andulogia , Bífaglia, Nausta, Gallatia, Aragoa, Valeatia, Catalogas Ifole Maiotica, \& Minotica.

La Contca di Borgogn

Tre Signotic ; cioe, is Frifia, \& Outificl, Maliats.

Quatro Decati, che fono Brabantia, Linaburg, Lecenbutg, so Gheldris.

Sci contadi ne'pacti, bafsi che fono la Fiandra, Namat, Artois, Hanonia Olanda \& Zelands.

II Regao di Napoli, di Cicilia , di Sardegna, \& lo fato di Milano. acsect

A Igieri, \& Tripo!

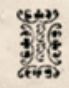

Nell'Africa ha if Turte

Quelli, che più de gli altri fono pratici panicolarmente dellecofede gli heria do Caua il Rè Catholico.

\section{Caua il Turco}

Delli Datij di Cantiglia, \& de gli affigamenti di Carlo quieto allImperatrice, va milioa d,oro, \& g6o.milia ducati.

Di Sixiglia , \&dell'entrate dello Almozarisfago maggiore, \& delli dritud delle metcantie diuetie cinquecento anilia ducati.

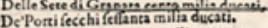

Del fertitio Montago 45-milia

$\therefore$

Del Sale 25y. milia.
Entrate diuerfe gli rendono og, milis dueati:

Quella che fic chiama Farda trentaciaque miliz

Githina delle Metcantic di Portugallo cento milis.

II Servitio ordinario, \& Atasordinario de'Regni di Spagas qoo.milis.

Merci, sh'efcono di Spagna, delle

Le coatributioni de'Mercanti che trafficano ne:I' Indie ss mallia.

Le minere de' Regai 265 .milia.
Di Catalogas, Valenzi, Aragon per lo feruitio delle corti di Monzos 44 . Mila

Glidritti celle Mercantie d'Orano gli danao s, milia.

Le merciche vengono di Fiandra, daghilterta, \& di Francia 8o.milia

Litre Macftrati, disantyago Alcantera, \& Calatraua 23 s.milia

Itherbe del campo di Calatraua, \& d'altri leoghi 95 -rai

L'Tndie va'anno per l'altro rendong
Altriauti iscuftidi 400 , milia.

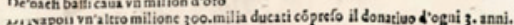

Di Milanorn'alter milione.

Di Cicilia pie di mezo milione, te

DiSardega ico,milia decati

$$
\text { Tutta quefta entrats fomma Milioni otto , * yog.milia decati. }
$$

La fpela di Sua M.C.e intorno a 6.milioni d'oro, di modo che v'ella non foffe per he fouerchie fpefe fatte nelle guerte paffate,di debitiaggratata, auiatabbe age

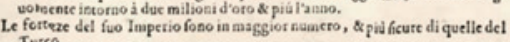
Turco

Soldsat di-i pagati fono ordinariamente 20,milia, \& voleadone, piu di cento milia ne pur fare ne gli flati fuon.

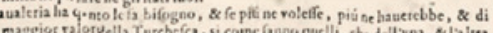

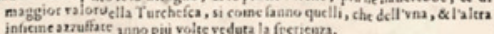

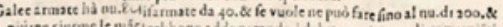

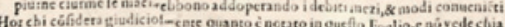

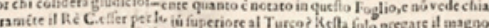

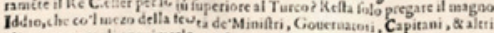

gli porga a atuto di oppriiuctio, -ftirpare del tetto quella actanda legge pes

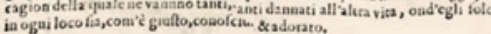

La Romanis, che comprende.

In Europa* Nell'A fia.

La Natolia, che comprende

L'Afiris, I'A rincain, Ia Media, la Perfia, la Soris, quello che polfiede de'Mori, la Cilicia, la Cappedocia , la Mefopontantis, la Burfia, Aleflandria, il Caito,
\& Cipri. de Preacipi,dicono che queti doo gran Principi tanao intorao ls infrafcrite entute. Dell' Afia vn millione, \& soo, mila ducati comptefo va ducato, z mezo, che paga ogai Chriftano quiui habitante.

Dello Eg gitto, Cairo, \&Anbia vn milione e 800.millias?

Dello Egitto, Cairo, \& Arbia vn milione e 800 . Della Meropotamis 200 . millin

Della Moldauia pertributo 160-milia.

Della Vallachia pertribeto i2.milia.

Della Tranfiluaaia per tributo ro.milia:

Di Ragufa per tributo 10.milia.

Di Scio per lo ifteffo gia 10.mili

Dello Arcipelago6.milia

Di Cipri altte volte 8.milis.

L'vrile delie patente,privilcgi, btevi, commandamenti , \& a letre fcritture publipe fonno 100 .milia.

Delle robbe, \& faculta di hi more fena hercdi caua 300.milia.

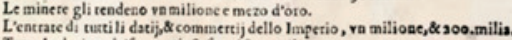
Tutse le decime de'frumenti, \& frutti $\$ 00$. milia.

La fomana di tuuta quefta entrata fono Milioni otto, ¿356.mulia decati.

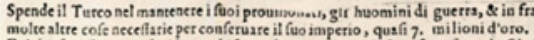
Eghi ie fuoi Regni, \&s fata ha pochifsime forterze: le quali fono tate fatte da Chri Ettiani, \& polciada lui occupate.

La nelitia de fooi Gianizari, in cur confiffe lo sforzo delle fwoi armi, èftimate in torno i 16 , milis.

II maggior nerwo defla fuo militia confifte nel numero di cento ottanta milia ca. uallichismati Saphi : le Quali forze fono atto folo d̀ guetreggiare in campagoe

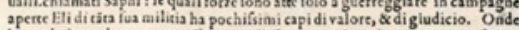
haucndo a combattere con effia geate di fermezza, \& ordinanza; come fonno Italiani, Spagnuoli, Tedefchi, k Francefi; ripportarebbe dilei certa vittoria effendo il valore di cotai popoli, \& la difciplina militare maggiore, \& di gra lunga pià eceellente della Turchicíca fi come molto ben fanao igiudicioti, \& eflcrcitati nell'arme militare.

Le forze di Mare fono flate vleim amente circa 20s. Galec;vas gra parte delle qua liegl' ha tolto a Chriltiani perto paffaso. Quando cinó hauefle la fedel ferui tì de' Rencgati, nulla, o poco ei potrebbe contra i Chriftiani, \& mafsime fe concentif me gli fono,cofi fedeli, \&eobedienti i fuoi.

IN PE R VIA per Pietropaolo Orlando Con Licentia de'Superiori.

Source: Archivo General de Simancas (AGS), Copia de la carta (1625), shelfmarked BNE, VC/224/64. 


\section{SOURCES AND LITERATURE}

\section{ARCHIVE DOCUMENTS:}

A. Hrvatski Državni Arhiv u Dubrovniku (HR-DAD)

Diplomata et Acta (DA.), Acta Turcarum (7/2.1):

sv. 16, br. 787 (A 8, 111) (Evâsıt-1 Şa 'ban 1035 / 8-17 May 1626);

sv. 22, br. 1027 (K 471) (Evâhir-i Cemâziye'l-âhir 1059 / 1-10 July 1649);

sv. 23, br. 1069 (K 513) (Evâil-i Rebi 'ü'l-âhir 1060 / 3-12 April 1650).

B. Ottoman Archive of Turkish State Archives (BOA)

1. Mühimme Defterleri (A. DVNS. MHM. d.)

No: 6, document no: 1145 and 1146 (14 Şevval 972 / 15 May 1565).

No: 7, document no: 1218 (10 Şevval 975 / 8 April 1568).

2. Maliyeden Müdevver Defter (MAD. d.), no: 6004

p. 14/1 (Evâhir-i Cemâziye'l-evvel 1030 / 13-22 April 1621);

p. 16/1 (Evâhir-i Cemâziye'l-evvel 1030 / 13-22 April 1621);

p. 113/2 (Evâhir-i Rebi'ü'l-âhir 1034 / 31 Ocak - 8 February 1625);

p. 125/3 (Evâsit-1 Şa ' ban 1035 / 8-17 May 1626).

C. ARCHIVO GENERAL DE SIMANCAS (AGS)

Copia de la carta (1625), shelfmarked BNE, VC/224/64.

\section{PUBLISHED SOURCES AND LITERATURE:}

Altinay, Ahmet Refik, Kösem Sultan, Kadınlar Saltanatı, Istanbul, 2011.

ARI, Bülent, Akdeniz'de Iki Süper Gücün Hakimiyet Mücadelesi, Ispanya ve

Osmanlı, Kibrıs Fethi - Inebahtı - Armada, Ankara, 2019.

Arikan, Muzaffer, Toledo, Paulino, XIV.-XVI. Yüzylllarda Türk-Ispanyol Ilişkileri ve Denizcilik Tarihimizle Ilgili Ispanyol Belgeleri, Ankara, 1995.

Aymard, Maurice, XVI. Yüzyılın Sonunda Akdeniz'de Korsanlık ve Venedik, trans. Mehmet Genç, Istanbul Üniversitesi Iktisat Fakültesi Mecmuası (IÜIFM), 26, Istanbul, 1963., 219-238.

BARbERo, Alessandro, Inebahtı, Üç Imparatorluğun Savaşı, Istanbul, 2016.

Biegman, Nicolaas H., Ragusan Spying for the Ottoman Empire. Some 16th Century Documents From the State Archive at Dubrovnik, Belleten, XXVII/106, Ankara, 1963., 237-255. 
Biegman, Nicolaas H., The Turco-Ragusan Relationship according to the Firmans of Murad III (1575-1595) extant in the State Archives of Dubrovnik, The HagueParis, 1967.

Bostan, Idris, Adriyatik Limanlarının Ticari Bakımdan Gelişmesine Korsanlığın Etkisi, XIV. CIEPO Sempozyum Bildirileri (18-22 Eylül 2000, Çeşme), Ankara, 2004., 18-22.

Bostan, Idris, Adriyatik'te Osmanlılar ve Uskoklar, Beylikten Imparatorluğa Osmanlı Denizciliği, Istanbul, 2007., (2nd edn.), 111-120.

Bostan, Idris, Adriyatik'te Korsanlik, Osmanlilar, Uskoklar, Venedikliler (15751620), Istanbul, 2009.

Braudel, Fernand, Akdeniz ve Akdeniz Dünyası, Vol. I-II, trans. Mehmet Ali Kılıçbay, Istanbul, 1989.

BÜYÜKAKsoy, Ahmet, Ingiltere'nin Istanbul Elçisi Thomas Roe'nun Diplomatik Yazışmaları (1621-1628) (master's degree thesis), Istanbul, 2012.

Cezar, Mustafa, Mufassal Osmanlı Taribi, Vol. III, Ankara, 2011.

Cipolla, Carlo M., Fatibler, Korsanlar, Tüccarlar, trans. Tülin Altınova, Istanbul, 2003.

FAroqhi, Suraiya, Osmanlı Dünyasında Üretmek, Pazarlamak, Yaşamak, trans. Gül Çağalı Güven and Özgür Türesay, Istanbul, 2008., (3rd edn.).

Fernández-Santos, Jorge, TabakoĞlu, Hüseyin Serdar, The Unexpected Ottoman Guest: Ahmed Agha in Madrid (1649-50), Ambassadors in GoldenAge Madrid, The Court of Philip IV through Foreign Eyes, eds. Jorge FernándezSantos and José Luis Colomer, Centro de Estudios Europa Hispánica, Madrid, 2020., 379-423.

Foretić, Vinko, Povijest Dubrovnika do 1808 godine, Vol. II, Ljubljana, 1980.

Gerlach, Stephan, Türkiye Günlüğ̈̈ 1577-1578, Vol. II, ed. Kemal Beydilli, trans. Türkis Noyan, Istanbul, 2007.

Glavina, Mladen, 17. Yüzyıl Başında Osmanlı Imparatorluğu ile Dubrovnik Cumburiyeti Ilişkileri (Master's Degree Thesis), Ankara, 2009.

GürkAN, Emrah Safa, Bir Diplomasi Merkezi Olarak Yeniçağ Istanbul'u, Antik Çăg'dan XXI. Yüzyıla Büyük Istanbul Tarihi, Vol. II (Siyaset ve Yönetim), ed. Coşkun Yılmaz, Istanbul, 2015., 372-399.

GüRKAN, Emrah Safa, Sultanın Casuslar, 16. Yüzyılda Istibbarat, Sabotaj ve Rüşvet Ağları, Istanbul, 2017.

HARRIs, Robin, Dubrovnik, A History, SAQI, Londra, 2003.

İlgürel, Mücteba, Kösem Sultan, Türkiye Diyanet Vakfi Islam Ansiklopedisi, XXVI, Ankara, 2002., 273-275. 
INALCiK, Halil, Osmanlı Imparatorluğu'nun Ekonomik ve Sosyal Taribi, Vol. I (1300-1600), ed. Halil İnalcık and Donald Quatuert, trans. Halil Berktay, İstanbul, 2004., (2nd edn.).

ÇELEBI, Kâtib, Fezleke [Osmanlı Tarihi (1000-1065/1591-1656)], Vol. I, trans. Zeynep Aycibin, Istanbul, 2016.

KIEL, Machiel, „Avlonya“, Türkiye Diyanet Vakfi Islam Ansiklopedisi (TDVIA), Vol. IV, Istanbul, 1991., 118-120.

KIEL, Machiel, „Draç“, TDVIA, Vol. IX, Istanbul, 1994., 522-524.

KoçU, Reşad Ekrem, Kösem Sultan, İstanbul, 2015.

Köse, Metin Ziya, Osmanlı Devleti ve Dubrovnik Cumburiyeti İlişkileri, 15001600, Doğu Akdeniz'de Casuslar ve Tacirler, Istanbul, 2009.

Kumrular, Özlem, Kurtlar Sofrasında Bir Cambaz: Şehir-Devlet Ragusa, Türk Tarihinde Balkanlar, Balkans in the Turkish History, Vol. I, eds. Zeynep İskefiyeli, M. Bilal Çelik and Serkan Yazıcı, Sakarya, 2013., 461-474.

LeE, Stephen J., Avrupa Tarihinden Kesitler 1494-1789, Ankara, 2019., (7th edn). Malcolm, Noel, Useful Enemies, Islam and the Ottoman Empire in Western Political Thought, 1450-1750, Oxford, 2019.

Miović, Vesna, Dubrovačka Republika u Spisima Osmanskih Sultana, Dubrovnik, 2005.

Miović, Vesna, Dubrovačka Diplomacija u Istanbulu, Hrvatska akademija znanosti i umjetnosti (HAZU), Zavod za povijesne znanosti u Dubrovniku, Zagreb-Dubrovnik, 2003.

Mumcu, Serap, Venedik Baylosu'nun Defterleri, The Venetian Baylo's Registers (1589-1684), Hilâl. 4, Edizioni Ca' Foscari, Venice, 2014.

NAKI, Emrah, Akdeniz'de Hakimiyet Mücadelesi, Istanbul, 2020.

ÖNAL, Ahmet, XVI. Yüzyılda Avrupa'daki Osmanlı Esirlerin Kurtarılması Meselesine Dair Bazı Gözlemler, Türkiye-Almanya Araştırmaları Dergisi, IV/1-2, Istanbul, 2015., 39-56.

Öztürk, Yücel, Özü'den Tuna'ya Kazaklar, Vol. I, Istanbul, 2004.

Polić-Bовіć, Mirjana, Među križom i polumjesecom. Dubrovačke dojave španjolskome dvoru o Turcima u XVI. stoljeću, Zagreb, 2000.

RIzAJ, Skender, „Dalmaçya“, TDVIA, Vol. VIII, İstanbul, 1993., 432-433.

RoE, Thomas, The Negotiations of Sir Thomas Roe, in His Enbassy to the Ottoman Porte, from the Year 1621 to 1628, London, 1740.

SANTOS, Jorge Fernandez and Serdar, Hüseyin, The Unexpected Ottoman Guest: Ahmed Agha in Madrid (1649-50), Ambassadors in Golden-Age Madrid, The Court of Philip IV through Foreign Eyes, ed. Jorge Fernández-Santos and José Luis Colomer, Madrid, 2020., 379-423. 
ŠUnDRICA, Zdravko, Obavještajna služba Dubrovačke Republike u 18. stoljeću (Epizoda austrijsko-turskog rata 1737.-1739.), Anali Zavoda za povijesne znanosti HAZU u Dubrovniku, 37, Dubrovnik, 1999., 157-204.

ТАва KoĞLU, Hüseyin Serdar, Osmanl-Ispanya Mücadelesi, Istanbul, 2019.

TADIĆ, Jorjo, Organizacija dubrovačkog pomorstva u XVI veku, Istorijski časopis, 1-2, SANU, Beograd, 1948., 54-104.

TADIĆ, Jorjo, Španija i Dubrovnik u XVI veku, Beograd, 1932.

Tenent I, Alberto, Piracy and the Decline of Venice, 1580-1615, trans. J. B. Pullan, Oxford-London, 1967.

UzUnÇA RŞılli, Ismail Hakkı, Büyük Osmanlı Tarihi, Vol. III, Ankara, 1995., (7th edn.).

Yemişçı, Cihan, 1618-28 Arası Osmanlı-Venedik Ilişkileri (master's degree thesis), Konya, 2009.

Yemişçı, Cihan, XVII. Yüzyılda Osmanl--Dubrovnik Siyasî Ilişkileri (doctoral dissertation), Istanbul, 2017.

Yemişçı, Cihan, VALJEVAC, Muhamed, Türk Esirlerin Kurtarılması ve Mübadelesinde Bir Merkez Olarak Dubrovnik ve 1575 ile 1592 Yıllarındaki Esir Mübadeleleri, Uluslararası Türk Savaş Esirleri Sempozyumu Bildiri Kitabı (14-15 Mart 2017, Istanbul), eds. Okan Yeşilot, Yüksel Çelik, Leyla Coşan and Ali Satan, Istanbul, 2018., 95-134.

ZIN KeISEN, Johann Wilhelm, Osmanlı İmparatorluğu Taribi, Vol. III-IV (12991453), ed. Erhan Afyoncu, trans. Nilüfer Epçeli, Istanbul, 2011. 


\section{Cihan YEMIŞÇI}

\section{DIPLOMATSKA KOMUNIKACIJA ŠPANJOLSKIH HABZBURGOVACA IZMEĐU DUBROVNIKA I ISTANBULA (1623. - 1626.)}

\section{SAŽETAK}

Iako su stvarna neprijateljstva već bila zaustavljena 1574. godine, Osmanskošpanjolski rat koji je trajao tijekom većeg dijela 16. stoljeća završitće poluslužebnim prekidom vatre 1578. godine. Primirja su produživana još nekoliko puta u kasnijim godinama i na tu formalnost, od 1591. godine i dalje, ne obraća se više pažnja. A kako bi, nakon tridesetogodišnjeg rata koji je u Europi započeo 1618. godine, učinkovitije iskoristila svoje vojne snage i financijske resurse, španjolska vlada nastoji umiriti Osmansko Carstvo ugovorom koji bi neutralizirao njegovu prijeteću prisutnost. S tim ciljem 1622. godine španjolski premijer Olivares organizirao je preko španjolskog vazala, napuljskog potkralja, da pošalje neke predstavnike kako bi osluhnuo političko raspoloženje u Istanbulu te otvorio put za zaključivanje sporazuma koji je Španjolska željela. Saznavši za namjere tih predstavnika koji su krenuli prema Istanbulu preko Dubrovnika, engleski veleposlanik Thomas Roe, u razdoblju između 1623. i 1626. godine, upušta se u diplomatsku borbu za zaštitu interesa i sigurnosti svoje zemlje. Roe nagovara francuske i venecijanske veleposlanike da se udruže s njim u postizanju njihovih zajedničkih ciljeva. Sastancima s osmanskim političarima i lobiranjem vodi diplomatski rat kako bi opstruirao planove španjolske vlade. Ovaj rad govori o španjolskim diplomatskim naporima u Istanbulu, između navedenih godina, te borbi da se osujeti alijansa veleposlanika u osmanskom glavnom gradu. Primarni izvori studije su objavljena pisma Thomasa Roea i dokumenti Državnog arhiva u Dubrovniku i Osmanskom arhivu u Odjelu državnog arhiva Turske.

Ključne riječi: Osmansko Carstvo, španjolski Habsburgovci, Istanbul, Thomas Roe, Dubrovnik, diplomacija. 